\title{
Budget perspective in \\ Croatia after accession \\ to the European Union
}

\author{
PETAR SOPEK*
}

Article**

JEL: F36

doi: $10.3326 /$ fintp.37.1.2

* The author is employed in Privredna banka Zagreb. The views expressed in this paper are exclusively those of the author and should not be attributed to Privredna banka Zagreb. The author thanks two anonymous referees for their insight, helpful comments and suggestions. One of the earlier versions of the paper was presented at the conference New Economic Challenges after EU Accession: What Awaits Us in the Long Run? organized by the Zagreb School of Economics and Management in Zagreb on May 18, 2012.

** Received: May 17, 2012

Accepted: September 2, 2012

Petar SOPEK

Privredna banka Zagreb, Radnička 48, 10000 Zagreb, Croatia e-mail: Petar.Sopek@pbz.hr 


\begin{abstract}
Upon accession to the European Union, the New Member State's budget undergoes significant structural changes due to the appearance of new categories of revenues and expenditures. The aim of this paper is to estimate the possible effects of Croatian membership in the EU on changes in the structure and size of budget revenues and expenditures upon the country's accession to the EU in the second half of 2013, as well as to indicate the possibilities for utilization of EU funds in the new financial perspective up to 2020. It is shown that in 2013 Croatia might realize a positive net financial position in transactions with the EU budget in the amount of approximately $0.28 \%$ of GDP, i.e. EUR $136 \mathrm{~m}$. The total net financial position of Croatia due to EU accession, which includes some additional costs and benefits like different harmonization and the need for project co-financing at state and local levels, is also positive in 2013 and amounts to approximately $0.15 \%$ of GDP or equivalently EUR $72 \mathrm{~m}$. Total amount of all funds that Croatia might receive in the new EU financial perspective covering the period from 2014 to 2020 amounts to EUR 6.34 bn, whereby annual amounts increase from EUR 0.7 bn in 2014 up to EUR 1.2 bn in 2020. By using exponential regression analysis it is estimated that in 2020 Croatia should be a net recipient of funds from the EU budget in total amount of $1.72 \%$ of GDP, i.e. EUR $1.13 \mathrm{bn}$.
\end{abstract}

Keywords: Croatia, European Union, fiscal policy, membership in the EU, net effects of accession, EU funds, New Member States

\title{
1 INTRODUCTION
}

The European Union (EU) continues preparation for its further enlargement. The accession negotiations with Croatia were closed on 30 June 2011, which allowed for the signature of the Accession Treaty on 9 December 2011. At a referendum held on 22 January 2012, 66.27\% of Croatian voters supported Croatian accession to the European Union. Following the ratification procedure in all EU Member States and Croatia, accession is foreseen for 1 July 2013 (Delegation of the European Union to the Republic of Croatia, 2012).

The EU membership generally brings an additional fiscal pressure on a Member State. It comes from the necessity to contribute to the EU budget, co-finance projects financed by the EU funds, pre-finance some of the EU transfers during first period of membership, as well as to continue implementation of the acquis communautaire in some costly areas such as environmental protection, infrastructure, border control and public administration (Antczak, Dabrowski and Gorzelak, 2004).

Building the administrative infrastructure in the pre-accession period is highly significant, not only for better coordination and management of pre-accession funds, but also for adequate preparation for use of the structural and cohesion related funds of the EU after membership status has been acquired. Institutions 
and human potentials included in processes of programming, implementation and evaluation of the EU funds are a key determinant of every country's absorption capacity and an indicator of preparedness for the effective usage of available funds.

Absorption of the EU funds generally depends on three main determinants, and these are: macroeconomic, financial and administrative, i.e. institutional absorption capacity. Macroeconomic absorption capacity is important as a country is not able to provide a sufficient number of productive investment opportunities to absorb the transfers in an efficient way if these transfers are high in relation to the national economic performance. Administrative absorption capacity is a decisive factor of success for the implementation of European structural policies. Financial absorption capacity defines the extent to which the supported regions are able to co-finance the projects, which becomes more difficult with a higher ratio of EU payments to GDP (Osterloh, 2010).

Financial absorption capacity, which is defined as the capability to co-finance the EU programs and projects, to plan and guarantee the government contribution in a multiannual budget and combine the contributions of the different partners included in the whole process, is directly linked to fiscal policy. This means that each accession country has to take care of the potential costs of the accession process in advance.

The annual average of estimated total costs before accession to the EU amounted to $3.2 \%$ of GDP in the case of the EU New Member States (i.e. the EU-10), of which $1.6 \%$ of GDP was averagely financed from the general government budget, but this amount varies from the minimum of $0.4 \%$ of GDP in the case of Poland to the maximum of $3.6 \%$ of GDP in Bulgaria (Antczak, Dabrowski and Gorzelak, 2004; Hallet, 2004). Even after accession to the EU, the New Member States incurred high fiscal costs for infrastructure development, as well as for public administration reform. The average share of these expenditures in GDP was estimated at $2-3 \%$ on an annual level in the eight countries that entered the EU on 1 May 2004 (Antczak, Markiewicz and Siwinska, 2006). Hence, the accession process leads to a negative net fiscal impact on the general government budget, which varies according to the degree of harmonization and can amount to as much as $3 \%$ of GDP in the first years after member status is obtained (Antczak, 2003).

The main objective of this paper is to estimate the possible effects of the Croatian accession to the EU on the structure and size of the revenue and expenditure of the Croatian budget upon the country's accession to the EU, i.e. in the second half of the year 2013, as well as to show the possibilities for the utilization of EU funds in the new financial perspective up to $2020^{1}$. A significant part of the analysis, with

\footnotetext{
${ }^{1}$ Throughout the text budget means the general government budget in every context, unless explicitly other-
} wise stated. 
some additional assumptions and corrections, will draw on the historical experiences of the New Member States, and the main sources of information used in the analysis are the financial reports of the European Commission on the realized budget revenues and expenditures in the period 2000 to 2010 (European Commission, 2011a; 2011b). However, it is important to stress that the actual and total effects of the EU accession on the Croatian budget cannot be exactly and fully assessed, since they depend on many internal and external factors. Thus, the analysis in this paper can provide only an insight into the size and expected direction of the effects of accession. Therefore, the research results should be interpreted with caution.

The introduction is followed by an overview of the existing system of EU budget revenues and expenditures. Since significant changes in EU budget financing in the period from 2014 to 2020 are envisaged, the third part of the paper provides a short overview of suggested reforms within a multiannual financial framework. The fourth part of the paper deals with qualitative and quantitative estimates of net financial effects of Croatian accession to the EU in 2013. The fifth part shows the mid-term perspective of Croatia in the period from 2014 to 2020, based on experiences of the EU New Member States and publicly available information on potential cash flows from the EU budget. After that follows the conclusion.

\section{EXISTING SYSTEM OF REVENUES AND EXPENDITURES OF THE EU BUDGET}

Upon accession to the EU, significant changes arise in the structure of budget revenues and expenditures, since part of a Member State's revenue is directly transferred to the EU budget according to standard mechanisms, while at the same time some new categories of revenues and expenditures appear in the budgets of Member States ${ }^{2}$. In the following text a synthesis of the main actual categories of revenues and expenditures will be given, while for the details on these budgetary items one may consult the existing literature (see for instance Kandžija and Cvečić, 2011; European Commission, 2011a; Cuculić, Faulend and Šošić, 2004; Sopek, 2011). This system of revenue and expenditure categories is valid only until the end of the year 2013, i.e. in the case of Croatia it will be in force only in the first half year of EU membership. In the new financial perspective covering the period from 2014 to 2020 certain changes in some revenue and expenditure categories are proposed, and they will be examined in chapter three. However, the financial perspective for the period 2014-2020 has still not been adopted, so it is uncertain whether these changes will be put in place.

Before, but also after, accession to the EU, countries are obligated to harmonize their tax and customs systems with the EU standards, which certainly leads to positive (an increase in budget revenues of a Member State) or negative (a decrease in budget revenues of a Member State) effects for the budget, depending on

\footnotetext{
${ }^{2}$ Revenue of the EU budget actually means budget expenditure from the perspective of the Member States.
} 
the level of harmonization of an accession country, i.e. Member State. However, besides the effects that joining the EU has on the current budget revenue (customs, VAT, excise duties), new categories of revenue appear as a result of transfers from the EU budget on the basis of participation in common EU policies. The positive side of getting transfers from the EU budget is manifested in a reduction of expenditure for financing the existing aid systems because the funds from the EU budget will be replaced with national funding (substitution effect).

Transfers from the EU budget can be divided into transfers that are not related to projects, so their amount automatically becomes the revenue of a Member State budget, and into transfers that depend on the absorption capacity of an individual Member State, which is primarily measured by administrative absorption capacity as a key determinant of the successfulness of implementation of EU structural policies, as well as financial absorption capacity as a measure of capability to cofinance projects at both state and local levels.

In the group of transfers not related to projects belong direct aids, agricultural market-related expenditure and transfers on the basis of internal policies. Direct support schemes for farmers not related to projects come from the Agricultural Fund, or more precisely from the part of it for guarantees, and they constitute an important part of the transfers from the EU budget. These mean direct aids (the largest share), refunds for the export of agricultural products to third countries, intervention measures for regulating the agricultural markets (for wine, fruit and vegetables, milk, sugar, etc.) and others. Transfers by means of internal policies include a variety of EU programs aimed at increasing the co-operation between Member States in the conduct of common policies, and these are for instance programs for investment in citizenship, freedom, security, justice, education, environmental protection, research, energy efficiency and so on. The main reason for the existence of these programs is that the EU considers that it is much better to implement common policies through various organizations, associations and legal entities, rather than by public authorities only.

In the group of transfers that depend on projects belong transfers from the Structural Funds, the Cohesion Fund and Rural Development Funds. Structural Funds have three main objectives: promotion of the development and structural adjustment of regions whose development is lagging behind, economic and social assistance to areas with structural difficulties, and assistance to adaptation and modernization of policies and systems for education, training and employment. Structural Funds cover exclusively regions whose GDP per capita is below $75 \%$ of the EU average and projects are co-financed by the EU up to maximum $75 \%$ of the eligible costs amount. Countries eligible for cohesion funding are those EU Member States with a gross national income lower than $90 \%$ of the EU average. The Cohesion Fund finances action on the trans-European transport networks, priority projects of special interest, as well as some other transport and 
environmental activities. Projects are co-financed by the EU up to maximum $85 \%$ of the amount of the eligible costs. Rural Development Funds mean financing from the European Agricultural Fund for rural development approved based on project plans, by which improvement in the consistency, transparency and clearness of rural development financing is fostered.

As well as those stated above, there is also a third group of transfers from the EU budget including other pre-accession assistances, special arrangements and budgetary compensations, but as compared to the other two components, this one has a relatively small significance in total EU budget (1.5\% in 2004, $0.4 \%$ in 2007, and $0 \%$ in 2010). Nevertheless, they were highly significant in the allocated amounts of New Member States in the first years of EU membership. These compensations are introduced in order to prevent New Member States becoming net contributors to the EU budget in their first years of the EU membership. So, for instance, in 2004 compensations had an average share of $35 \%$ of total allocated funds to New Member States, with 73\% in the case of Cyprus, 70\% in the case of Malta, $41 \%$ in the case of Czech Republic and $37 \%$ in the case of Slovenia. If these amounts are enlarged by other pre-accession assistances, these two components together represent an average of 55\% of total allocated funds to EU New Member States in 2004 (European Commission, 2011b).

In addition to the above mentioned items that impact the revenue side of the EU budget (at the same time some of them also impact the expenditure side due to the need for project co-financing), there are also some new expenditure categories of EU Member States. Own resources of the EU budget are automatically transferred from the Member States' budgets into the EU budget and for these revenues no individual national authority decision is necessary. Own resources of the EU budget are: Traditional Own Resources (TOR), revenue from Value Added Tax (VATbased revenue) and revenue based on Gross National Income (GNI-based revenue). A special part of the EU's own resources consists of various corrections, of which the most important is the UK correction ${ }^{3}$.

Traditional Own Resources consist mainly of customs, agricultural duties and sugar levies, whereby $75 \%$ of all collected revenue on this basis is automatically transferred to the EU budget, while the remaining part of $25 \%$ is kept by a Member State to defray the costs of their collection ${ }^{4}$. Hence, it can be concluded that there is a double loss for a Member State government budget, which includes direct loss due to automatic transfer to the EU budget, as well as indirect loss due to harmonization with the EU customs tariff structure.

\footnotetext{
${ }^{3}$ As well as the correction for the United Kingdom, there are also correction mechanisms for other largest net contributors - Austria, Germany, Netherlands and Sweden. These corrections are considered in text within specific component of EU budget revenue to which they relate (within UK correction, VAT-based revenue and GNI-based revenue).

${ }^{4}$ Since the retained amounts of $25 \%$ of total collected Traditional Own Resources do not correspond to actual collection costs, this model can be considered a hidden correction mechanism (European Commission, 2011g).
} 
VAT-based revenues are calculated as a predefined percentage of a VAT base, which has to be harmonized with EU rules. Still, in order to prevent disproportional payments into the EU budget, the VAT base is capped by $50 \%$ of a Gross National Income ${ }^{5}$. However, although disproportioned payment based on VAT is partly restrained, it has not been fully eliminated. According to European Commission (2011g), the size of the VAT base is not in practice proportional to Member States' GNI. Some of the richest Member States, such as Luxembourg and to a lesser extent Ireland, are subject to capping and thus see their contributions reduced. Since 1 January 2007, a uniform rate of $0.3 \%$ has been applied on the VAT base or $50 \%$ of the Gross National Income, whereby special exceptions are defined for Austria $(0.225 \%)$, Germany $(0.15 \%)$, Netherlands $(0.1 \%)$ and Sweden $(0.1 \%)$.

\section{Figure 1}

EU budget expenditure by main categories in the period 2007-2010 (in bn euro)

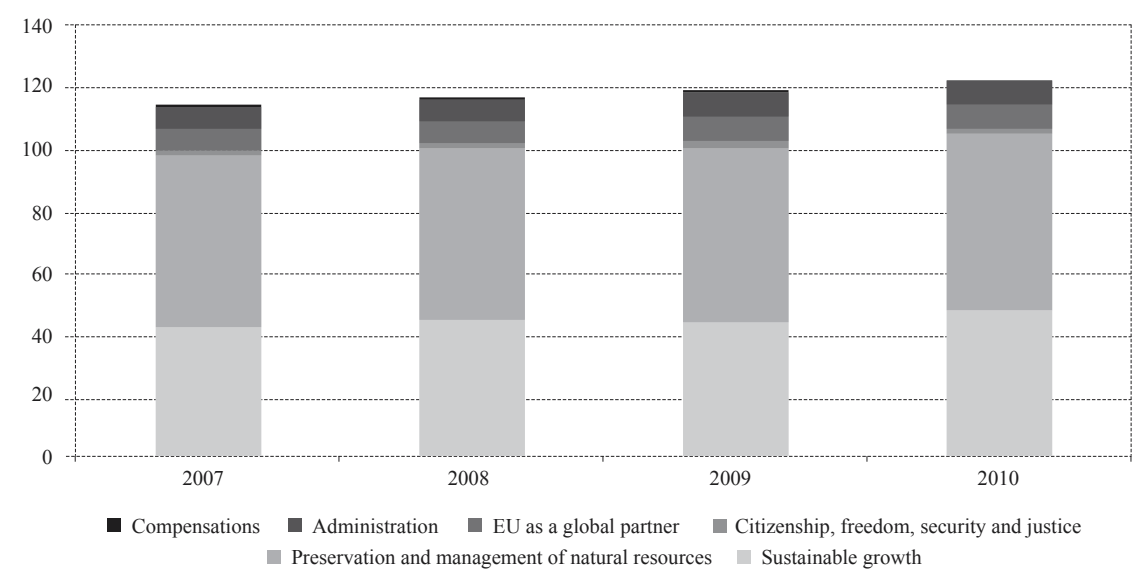

Source: Author's calculation based on European Commission (2011b).

GNI-based revenues are definitely the biggest burden for the national budget of EU Member States. The total revenue of the EU budget on the basis of GNI is calculated as the difference between total EU budgetary expenditure and revenue collected on other bases. In other words, this revenue patches holes in the EU budget and every EU Member State pays in its own part on the basis of the relative size of its GNI. A special privilege of a lump sum deduction of the GNI-based revenue has been approved to Netherlands and Sweden, amounting to EUR 605 bn per annum for the Netherlands and EUR 150 bn per annum for Sweden, calculated at constant prices for 2004.

\footnotetext{
${ }^{5}$ If the VAT base of a country exceeds $50 \%$ of the GNI, the applicable rate is $0.3 \%$ on $50 \%$ of the GNI. This limitation was introduced because it was shown that the consumption of less prosperous countries, and therefore the VAT base, record higher shares of the country's GNI. Without this restriction, relatively less developed countries would pay out of proportion to their contributive capacity into the EU budget (European Commission, 2011a).
} 
An additional cost to a Member State budget is also the UK correction. Namely, after joining the EU the United Kingdom became the largest contributor to the EU budget, mostly thanks to the low level of transfers from the Common Agricultural Policy (CAP) due to its relatively small agricultural sector. Thus, since 1985 the United Kingdom has been refunded a part of its payment into the EU budget in the amount of $66 \%$ of its net position. The loss of this revenue is made up together by all other Member States, with the provision that Germany, Netherlands, Austria and Sweden (the largest net contributors) bear only one quarter of the share.

\section{Figure 2}

\section{EU budget revenue by main categories in the period 2007-2010 (in billion euro)}

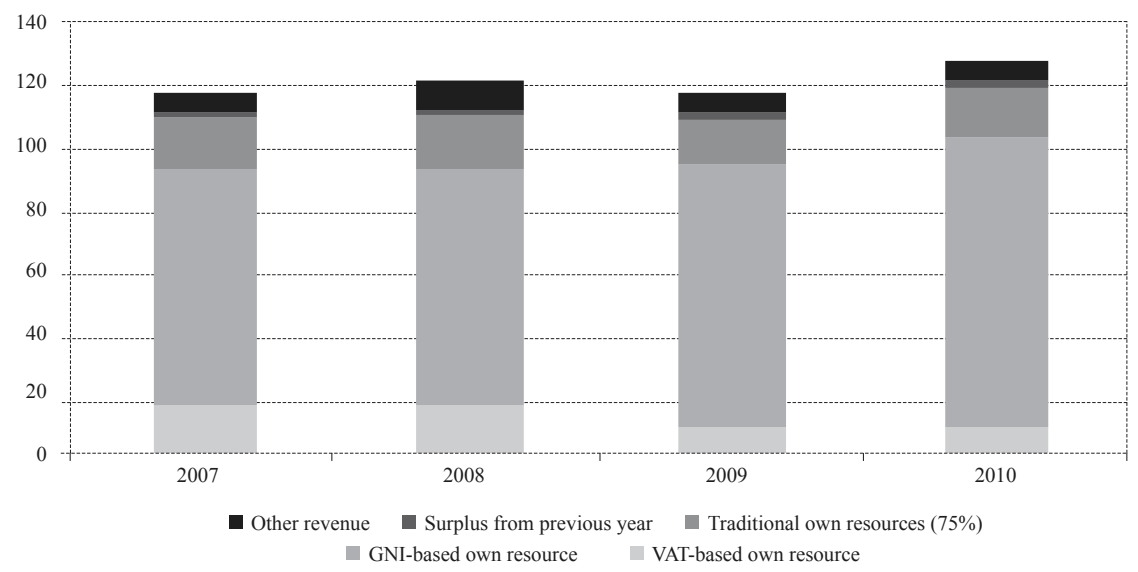

Source: Author's calculation based on European Commission (2011b).

Total EU budget expenditures amounted to EUR 122 bn in 2010. The largest part relates to categories Preservation and Management of Natural Resources (46\%) and Sustainable Growth (40\%). Lower shares in total expenditure represent the categories EU as a Global Partner (6\%) and Administration (6\%). Preservation and Management of Natural Resources mainly consists of market-related expenditure and direct aids (78\%) and Rural Development Funds (20\%). The Sustainable Growth category is divided into two subcategories. The first one is Cohesion for Growth and Employment, representing 76\% of all Sustainable Growth funds, and this category includes Structural Funds (79\% of Cohesion for Growth and Employment funds) and the Cohesion Fund (21\%). The other category within Sustainable Growth is Competitiveness for Growth and Employment with share of $24 \%$, and this category includes various programs for fostering research activities, innovation, lifelong learning and social policies development. EU budget expenditures have been recording a continuous increase in each year. Total expenditures in 2010 are $7 \%$ higher than those in the year $2007,22 \%$ than those of 2004 and $46 \%$ higher than the total expenditure recorded in 2000. The highest annual increase of as much as $11 \%$ was recorded in 2004 , primarily due to the 
enlargement of the EU by the inclusion of the New Member States. The highest shares of the EU budget funds in 2010 were allocated to Spain (10.8\%), France (10.7\%), Germany (9.7\%) and Poland (9.7\%). However, an analysis of the paid amount of funds from the EU budget with regard to Member States' GNI shows that the largest shares in 2010 were received by Lithuania (5.9\%), Estonia (5.8\%), Luxembourg (5.2\%) and Latvia (4.6\%).

Total EU budget revenue in 2010 amounted to EUR 128 bn, of which the largest part relates to GNI-based revenue (71\%). Traditional Own Resources represented approximately $12 \%$ and VAT-based revenue about $10 \%$ of total EU budget revenue. Various corrections that represent significant shares in Member States' budgets are irrelevant in the overall EU budget, since in the overall EU budget only their net position is recorded (payments of Member States into the EU budget minus payments from the EU budget, primarily to the United Kingdom). Unlike the EU budget expenditures that have been constantly recording an increasing trend, EU budget revenues have had a somewhat different situation, mainly resulting from the impact of the global crisis. The impact of the crisis was best seen in a comparison of 2009 and 2008, since VAT-based revenue decreased by 33\%, and Traditional Own Resources by 16\%. Subsequently, this led to an increase in GNIbased revenue by $10 \%$. The largest contributors to the EU budget in 2010 were Germany (20.0\%), France (16.4\%), Italy (12.9\%) and United Kingdom (12.3\%) With respect to GNI, the largest contributor in 2010 was Belgium, which paid $1.34 \%$ of its GNI into the EU budget.

\section{NEW EU FINANCIAL PERSPECTIVE FROM 2014 TO 2020}

For the period 2014-2020 new EU financial perspective is envisaged; it is described in the Multiannual Financial Framework named "A Budget for Europe 2020" (European Commission, 2011d; 2011e) as well as in the whole set of supplements and amendments of this document (see for instance European Commission, 2011f; $2011 \mathrm{~g}$ ). These documents propose numerous changes in the financing policies of the EU budget, i.e. its revenue and expenditure. The main changes in the period from 2014 to 2020 envisaged by the new financial perspective proposal, actual at the moment of writing this paper, will be described below. However, new financial perspective proposal is still uncertain; indeed, it is highly unlikely that some of the proposals will in the end be adopted and applied in the new financial perspective.

\subsection{PROPOSED CHANGES IN THE EU BUDGET REVENUES}

In the financing of the EU budget in the period 2014-2020 a reform of the own resources system is proposed, by which current VAT-based own resources would be significantly changed and new own resources based on a part of the proceeds of a financial transaction tax (FTT) would be created. The purpose is not to increase the overall EU budget, but to contribute to national budgetary consolidation

\footnotetext{
${ }^{6}$ Without correction, the share of United Kingdom would amount to $15.3 \%$ of total payments into the EU budget.
} 
efforts by reducing direct contributions from Member State budgets. The changes proposed will also simplify the existing contributions to the budget and increase the link between EU policies and EU financing (European Commission, 2011h).

Financial sector taxation would constitute a new revenue stream, therefore potentially reducing the existing contributions from Member States, giving extra room for maneuver to national governments and contributing to general budgetary consolidation efforts. A financial transaction tax that could be collected at the EU level would also reduce the juste retour problems observed in the current financing system. An EU initiative in this area would constitute a first step towards the application of an FTT at the global level. The financial transaction tax model proposed by the European Commission would consist of two different rates, whereby trading with bonds and shares would be taxed at the rate of $0.1 \%$, while for other financial instruments (derivative products) a rate of $0.01 \%$ would be applied (European Commission, 2011g). By the amended proposal for a Council Regulation laying down implementing measures for the system of own resources of the European Union it is envisaged that two thirds of a future financial transaction tax would be used for financing of the EU budget, while the resting part would be kept in Member State budgets (European Commission, 2011j). This tax raises many debates and disagreements among Member States and its final application is therefore still uncertain, since for the adoption of this taxation model a consensus of Member States is needed.

The biggest opponent to the introduction of the financial transaction tax is the United Kingdom whose House of Lords in its report claims that there is a significant risk that financial institutions would relocate outside the EU if the FTT is introduced. It has been suggested that the FTT may be adopted by some or all Euro Area Member States, or that a tax of a similar kind to the UK Stamp Duty might be pursued (House of Lords, 2012). Also very much opposed to the introduction of financial transaction tax is Sweden, which introduced similar tax in 1984. This tax did not prove to be successful, so in 1991 Sweden decided to repeal it. Apart from the United Kingdom and Sweden, Luxembourg, Netherlands and Malta also argue for the rejection of the proposal for the introduction of FTT. Ireland is against the mentioned proposal in case it is applied to some EU Member States only. On the other hand, the biggest champions of the introduction of FTT are Germany and France, stressing that it could help in distributing the crisis burden to financial institutions, but could be also used for financing of banks seeking bailouts. Apart from Germany and France, positive opinions on the introduction of the FTT are also voiced by Austria, Belgium, Portugal, Slovenia, Spain, Greece, Slovakia and Estonia.

For the calculation of new VAT-based own resources it has been proposed to employ a simple method by which a certain share of funds collected by the national tax administration would be transferred to the EU budget. On the basis of the VAT 
returns, the tax administrations would apportion the VAT receipts between the VAT stemming from the standard rate and the reduced rates and would then exclude from the former, on the basis of national accounts data, consumption data or other sources, the VAT stemming from the few transactions not subject to the new VAT resource. Unlike the existing VAT-based own resource, the revenue stream would not be capped and would not be the result of the current complex statistical calculations and adjustments to obtain a purely theoretical VAT base. It would result from the actual new VAT resource paid by all the European final consumers and then collected by the national tax authorities. Moreover, this system would closely link EU policies for VAT with EU budget policies (European Commission, 2011g). EU budget revenue would increase in the case of a broadening of a national VAT base, which can result from broadened list of taxable goods and services, i.e. from reduced exemptions in VAT system, or due to increased consumption. Moreover, EU budget revenue would increase also in the case of a reduction in the number of deliveries currently taxed by zero or reduced rates, since a standard VAT rate would then be applied to these deliveries of goods and services and in this case these VAT revenues would be subject to the application of a taxation rate for transfer to the EU budget. According to European Commission (2011i) the tax rate applied should not exceed $2 \%$, and it is proposed that there should be the application of a tax rate of $1 \%$ of the net value of supplies of goods and services, intra-Community acquisitions of goods and importation of goods subject to a standard rate of VAT in every Member State determined according to Union rules (European Commission, 2011j). Figure 3 shows realized VATbased revenue (\% of GNI) with regard to GDP per capita PPS in 2009 and estimated VAT-based revenue according to new EU budget proposal.

Revenue estimates of European Commission (20111) for a single-rated VAT resource applied to a harmonized basis show that the VAT burden in Cyprus, Malta and Luxembourg would clearly be higher than the average, while Latvia, Slovakia and Romania would benefit from lower VAT charges. Figure 3 shows that the introduction of new VAT-based own resource would only partially reduce disproportional payments into the EU budget with regard to the development level of a Member State. While the average VAT-based own resource increase compared to the current model on the level of EU-27 should amount to approximately $267 \%$, the highest increase is estimated in Netherlands and it amounts to $722 \%$ (from $0.05 \%$ to $0.39 \%$ of GNI). As there is a strong correlation between VAT bases and GNI, it can be expected that a new VAT resource could bring stable and sufficient revenue for a budget evolving broadly in line with the GNI of Member States (European Commission, 20111).

Apart from the above mentioned new categories of EU budget revenue, some changes in existing revenue categories have also been initiated, primarily related to simplification of correction mechanisms by replacing the current complicated system with a simple system of lump sum reductions to the GNI-based contributions 
paid by Member States. The proposed reform is based on the Fontainebleau principles agreed in 1984, whereby any Member State sustaining a budgetary burden which is excessive in relation to its relative prosperity may benefit from a correction at the appropriate time (European Commission, 2011h). As well as changes in corrections, a change of Traditional Own Resources policy is also envisaged. In view of the proposal to incorporate the correction mechanisms into lump sums, the retention should be restricted to $10 \%$, instead of $25 \%$, which is also in line with the system in place until 2000 (European Commission, 2011i).

\section{FiguRE 3}

Realized VAT-based revenue (\% of GNI) with regard to GDP per capita PPS in 2009 and estimated VAT-based revenue according to a new EU budget proposal
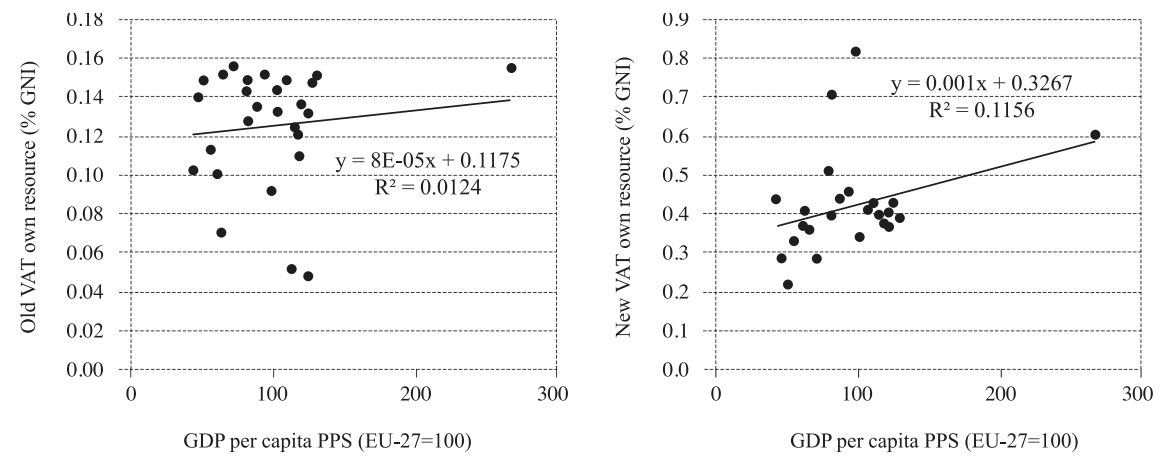

Source: Author's calculation based on European Commission (2011b, 2011l) and Eurostat.

\section{TABLe 1}

Estimated changes in structure of EU budget financing (in billion euro and $\%$ of own resources)

\begin{tabular}{|c|c|c|c|c|}
\hline & \multicolumn{2}{|c|}{ Budget proposal 2012} & \multicolumn{2}{|c|}{2020} \\
\hline & $\begin{array}{c}\text { Billion } \\
\text { euro }\end{array}$ & $\begin{array}{l}\% \text { of own } \\
\text { resources }\end{array}$ & $\begin{array}{c}\text { Billion } \\
\text { euro }\end{array}$ & $\begin{array}{l}\% \text { of own } \\
\text { resources }\end{array}$ \\
\hline Traditional own resources & 19.3 & 14.7 & 30.7 & 18.9 \\
\hline Member States' contribution & 111.8 & 85.3 & 95.0 & 58.4 \\
\hline VAT-based own resources & 14.5 & 11.1 & 29.4 & 18.1 \\
\hline GNI-based own resources & 97.3 & 74.2 & 65.6 & 40.3 \\
\hline New own resources & - & - & 37.0 & 22.7 \\
\hline $\begin{array}{l}\text { Financial transactions } \\
\text { taxation }\end{array}$ & - & - & 37.0 & 22.7 \\
\hline Total & 131.1 & 100.0 & 162.7 & 100.0 \\
\hline
\end{tabular}

Source: European Commission (2011k); author's adjustment.

According to estimates of European Commission (2011k), new proposal of EU budget financing would significantly impact the structure of own resources. It 
shows the shift from the existing national contributions towards the new own resources. Unlike the current model, by which a major part of revenue is transferred to the EU budget based on a Member State's GNI (GNI-based revenue and partially VAT-based revenue), the new own resources system would decrease Member States' contribution based on GNI to around 40\%. Taxation of financial transactions would constitute almost one fourth of EU budget revenue. Moreover, in the total revenue structure the contribution of Traditional Own Resources would also increase from approximately $15 \%$ to $19 \%$ (increase by $29 \%$ ), and the contribution of VAT-based own resources would go up from $11 \%$ to somewhere in the region of $18 \%$ (increase by $63 \%$ ).

\subsection{PROPOSED CHANGES IN THE EU BUDGET EXPENDITURES}

Items of proposal of the EU budget expenditures are always expressed in parallel in two different ways, i.e. showing separately commitment appropriations and payment appropriations. The main reason for such demonstration of budget planning is that an increasing part of expenditures relates to multiannual projects, so the payments are usually made over several years. Hence, commitment appropriations represent the total costs in the current financial year of the legal obligations entered into for operations to be carried out over more than one financial year. This type of appropriation constitutes the upper limit of expenditure that can be committed during the financial year. On the other hand, payment appropriations cover expenditure arising from commitments entered into during the current financial year or preceding years, but these do not include amounts related to a specific year that will be payable in some later period.

According to European Commission (2011h), the overall commitment ceiling proposed by the Commission for the 2014-2020 period (EUR 1,025 bn) is around 3\% higher than EU budget expenditures appropriated for the period 2007-2013 (EUR 994 bn). With regard to Gross National Income, the total amount of commitment appropriations for the period 2014-2020 will be lowered to $1.05 \%$ of expected EU GNI, compared to $1.12 \%$ of GNI in the current multiannual financial framework (2007-2013).

On the other hand, the overall ceiling for payments proposed by the Commission for the 2014-2020 period (EUR 972 bn) is also around 3\% higher than EU budget expenditures appropriated to the period 2007-2013 (EUR 943 bn). With regard to the Gross National Income, the total amount of payment appropriations for the period $2014-2020$ will be lowered to $1.00 \%$ of EU GNI, compared to $1.06 \%$ of GNI for the 2007-2013 period.

Definitely, one novelty is that the European Commission is presenting for the first time consolidated expenditures for the period 2014-2020, alongside the multiannual financial framework, which in total represent $1.11 \%$ of EU GNI (CPMR, 2011). Consolidated expenditures mean a number of flexibility instruments which 
are traditionally outside the multiannual financial framework because they are not programmable. In this category are Emergency Aid Reserve, European Globalisation Adjustment Fund, Solidarity Fund, Flexibility Instrument, etc. However, if during an emergency the budgetary authority decides to activate additional funds, they are entered into the annual EU budget. In addition, the European Development Fund is financed outside the budget due to a different financing key (European Commission, 2011h).

Structures of EU budget expenditures by main categories in the period 2007-2013 and in the new financial perspective from 2014 to 2020 are shown on figure 4 .

\section{Figure 4}

Structure of EU budget expenditure by main categories in periods 2007-2013 and 2014-2020 (in \%)

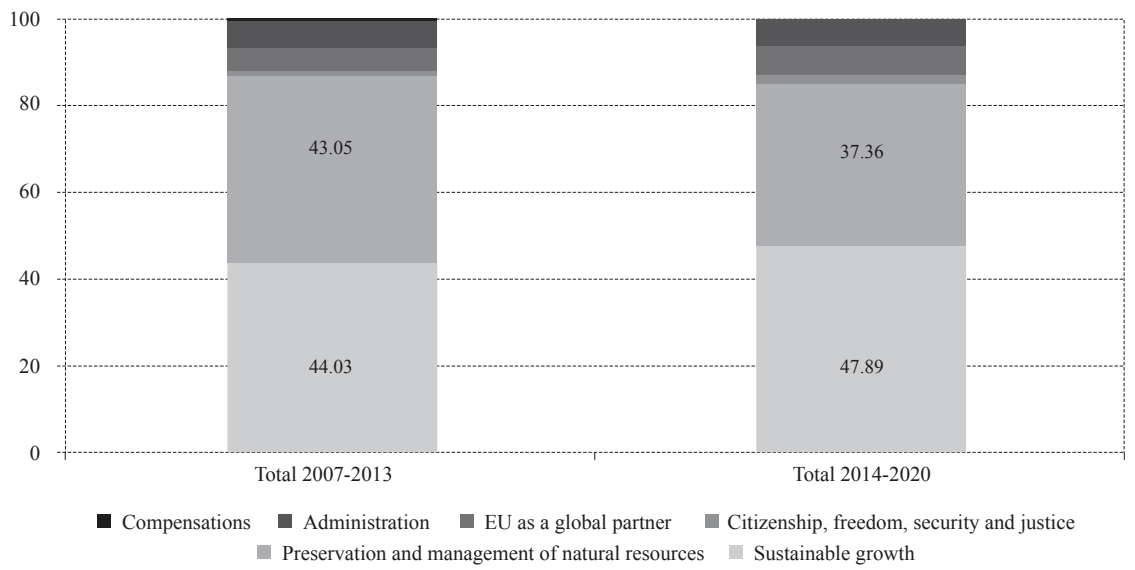

Source: Author's calculation based on Council of the EU (2005) and European Commission (2011h)

The categories Sustainable Growth and Preservation and Management of Natural Resources represent over five sixths of total EU budget expenditures, i.e. $87 \%$ in the period $2007-2013$ and $85 \%$ in the period 2014-2020. The categories EU as a global player and Administration represent lower shares in total expenditures, i.e. $6-7 \%$ and $6 \%$ respectively. As compared to the financial perspective 2007-2013, in the new financial perspective 2014-2020 certain changes are proposed in the structure of expenditures, meaning that according to the actual proposal the category Sustainable Growth would be increased from $44 \%$ to $48 \%$ of total expenditures, while the category Preservation and Management of Natural Resources would be decreased from $43 \%$ to $37 \%$ of total expenditures.

In general, in the period 2014-2020 the Common Agricultural Policy and Cohesion Policy remain the EU's two biggest budgetary items (respectively $36.3 \%$ and 

External Aid (+25\%) in particular (CPMR, 2011).

Cohesion policy continues to be concentrated on the less developed regions and Member States with GDP per capita less than $75 \%$ of the European average (so called convergence regions). The moderate reduction in the Cohesion Policy budget can be partly explained by the fact that some regions have phased out of the convergence objective. Within the Cohesion Policy it is planned to create a new category (so called transition regions), which will concern regions whose GDP per capita is between $75 \%$ and $90 \%$ of the EU average. Among these regions, those phasing out of the convergence objective will benefit from a "safety net" equivalent to two-thirds of their current budget allocation (CPMR, 2011). There are also so called competitiveness regions, covered by the Regional Competitiveness and Employment program, whose GDP per capita is at least $75 \%$ of the EU average. The amount of resources allocated to these regions depends on their unemployment rate, employment in less prosperous economic sectors, level of education, population density, etc. (Kandžija and Cvečić, 2011).

According to proposal of European Commission (2011d), Cohesion Policy funds in a total amount of EUR 376 bn, including both Structural Funds and Cohesion Fund, will be allocated to the following segments:

- EUR 162.6 bn (43\%) to convergence regions;

- EUR 38.9 bn (10\%) to transition regions;

- EUR 53.1 bn (14\%) to competitiveness regions;

- EUR 11.7 bn (3\%) to territorial cooperation;

- EUR 68.7 bn (18\%) to the Cohesion Fund.

Besides that, EUR 40 bn (11\%) will be allocated to the Connecting Europe Facility in the following amounts: EUR 9.1 bn to the energy sector, EUR 21.6 bn to transport (including additional EUR 10 bn that will be secured within Cohesion Fund) and EUR 9.1 bn to information and communication technologies.

Delays in the preparation of projects, commitments and spending are responsible for an important backlog of unused appropriations at the end of the present financing period. Furthermore, the fiscal situation in some Member States has made it more difficult to release funds to provide national co-financing. Experiences with the current financial framework show that many Member States have difficulties in absorbing large volumes of EU funds over a limited period of time. In order to strengthen absorption of funding the European Commission (2011d) proposed three steps related to cohesion policy:

- to fix the capping rates for cohesion allocations at $2.5 \%$ of GNI; 
- to allow for a temporary increase in the co-financing rate by 5 to 10 percentage points, thus reducing the effort required from national budgets at a time of fiscal consolidation, while keeping the same overall level of EU funding;

- to include certain conditions in the partnership contracts regarding the improvement of administrative capacity.

The Common Agricultural Policy (CAP) comprises two basic pillars, and these are agricultural market measures (first pillar) and the Rural Development Funds (second pillar). The new proposal of European Commission (2011d) suggests that CAP in the new financial perspective contains a "greener" and more equitably distributed first pillar and a second pillar that is more focused on competitiveness and innovation, climate change and the environment. On this basis a total of EUR 281.8 bn will be allocated for the first pillar and EUR 89.9 bn for the second pillar for the whole period 2014-2020.

New Common Agricultural Policy (European Commission, 2011d) introduces three novelties, and these are as follows:

- Greening of direct payments, which means that $30 \%$ of direct support to farmers is being made conditional on "greening", ensuring that the CAP helps the EU to deliver on its environmental and climate action objectives, beyond the cross-compliance requirements of current legislation. This means that all farmers must engage in environmentally supportive practices which will be defined in legislation and which will be verifiable. The impact will be to shift the agricultural sector significantly in a more sustainable direction, with farmers receiving payments to deliver public goods to their fellow citizens.

- Convergence of payments, by which the levels of direct support per hectare will be progressively adjusted, taking account of the differences that still exist in wage levels and input costs, in order to ensure a more equal distribution of direct support. This will be achieved in a way that, over the period, all Member States with direct payments below the level of $90 \%$ of the EU average will close one third of the gap between their current level and this level. This convergence will be financed proportionally by all Member States with direct payments above the EU average. Equally, the allocation of Rural Development Funds will be revisited on the basis of more objective criteria and better targeted to the objectives of the policy. This will ensure a fairer treatment of farmers performing the same activities.

- Capping the level of direct payments by limiting the basic layer of direct income support that large agricultural holdings may receive, while taking account of the economies of scale of larger structures and the direct employment these structures generate. The Commission proposes that the savings be recycled into the budgetary allocation for rural development and retained within the national envelopes of the Member States in which they originate. 
The allocation of Rural Development Funds should be based on more objective criteria and better targeted to the aims of the policy. This would ensure a fairer treatment of farmers performing the same activities (European Commission, 2011h).

Apart from the Cohesion Policies included in category I. Smart and Inclusive Growth and Common Agricultural Policies in category II. Sustainable Growth: Natural Resources, the EU also plans expenditures in the total amount of EUR $151 \mathrm{bn}$, distributed among the following categories:

- Security and citizenship - EUR 18.5 bn ( $2 \%$ of total EU budget in the period 2014-2020);

- Global Europe - EUR 70.0 bn (7\%);

- Administration - EUR 62.6 bn (6\%).

\section{EFFECTS OF THE ACCESSION ON THE CROATIAN BUDGET IN 2013}

Upon the accession of Croatia to the European Union, the Croatian budget will encounter numerous structural changes, of which some will have only a one-time effect, visible in the year 2013, while some of them will permanently impact budgetary cash flows. In this part of the paper the basic objective is to estimate the real effects of accession on the Croatian budget in 2013, which will be also the last year of the current financial perspective 2007-2013, while potential effects in the period from 2014 to 2020 will be closely examined in the following part of the paper.

Before, but also after, accession to the EU, countries are obligated to harmonize their tax and customs systems with the EU standards. Croatia has almost fully performed this harmonization. According to the Croatia 2011 Progress Report (European Commission, 2011c), Croatian legislation regulating indirect taxation is largely in line with the EU acquis, but further alignment is required in the field of VAT, notably on the scope of the reduced rates and of exemptions, free zones and special schemes.

In Croatia a zero VAT rate is still applied to a certain group of products, while the European Union prescribes the usage of a maximum of two reduced rates that may not be lower than 5\% (Council Directive 112/2006/EZ of the European Union, 2006). Sopek (2012) estimates that upon harmonization of the reduced rates with the EU Directive, with the assumption of all other rates being unchanged, government revenue will increase by an amount equal to $0.4 \%$ of GDP in the case of the application of the lowest prescribed VAT rate of $5 \%$ on deliveries that are currently taxed at the zero rate, or analogously $0.8 \%$ of GDP in case of application of a VAT rate of $10 \%$. 
Due to harmonization of Croatian excise duties system with the EU Directives additional harmonization in the field of excise duties with regard to chargeability of duty on coal, gas and electricity and minimum rates can be expected (European Commission, 2011c). The Screening Report for Croatia on Chapter 16 - Taxation for the period up to March 2010, states that, aiming at the harmonization of the Croatian excise duties legislation with the acquis, Excise Duties Act (NN 83/09) was adopted, entering into force on 1 January 2010. The Act is aligned with the horizontal Directive 92/12/EEC on excise duties and with the acquis concerning the harmonized excise duties levied on alcohol and alcoholic beverages, tobacco products and energy products (Government of Republic of Croatia, 2010a). Afterwards, the Regulation on the Excise Duty Rate on Tobacco Products (NN $102 / 10$ ) proposed an increase in proportional excise duties from $30 \%$ to $33 \%$ of the relevant retail selling price. Due to this increase, the share of overall excise duty (specific plus proportional excise) increased approximating the minimum rate of $57 \%$ of the retail selling price required under European legislation (Kuliš, 2010). With regard to the obligation of reaching an overall excise duty on cigarettes of at least $60 \%$ of the weighted average retail selling price of cigarettes released for consumption and the minimum requirement of EUR 90 per 1,000 cigarettes up to 1 January 2012, Croatia has requested a transitional period until the end of 2017 to meet the mentioned requests, as was envisaged for certain EU Member States. Moreover, Council Directive 2008/118/EC of 16 December 2008, which entered into force on 1 April 2010, introduced a legislative framework for computerizing the movement and surveillance of excisable products. Following the technical consultations with European Commission representatives, Croatia should harmonize its excise duties legislation with Council Directive 2008/118/EC no later than up to the moment of accession to the EU. In the same period Croatia should also enforce amendments of the Excise Duties Act in part related to accounting accruals of excise duties on natural gas and electricity (Government of Republic of Croatia, 2010b). Since there is no publicly available analysis of the possible financial implications of the above mentioned harmonizations, and having in mind that the major categories of excise duties are already harmonized with the EU Directives ${ }^{7}$, for the analysis hereafter it will be assumed that the total net effect will be negligible. Still, it is suggested that a detailed analysis of misalignments of Croatian and European excise duties system be initiated, and the net effect of their harmonization estimated. Apart from the potential costs or benefits to the general government budget, this analysis should definitely include potential impacts to the total costs of tax authorities, i.e. administrative and compliance costs of taxation, as well as other costs induced by economic distortions generated by the nature of these taxes like changes in demand for these products and consequently changes in the prices and supply of these products.

\footnotetext{
${ }^{7}$ This primarily relates to excise duties on petroleum products $(53 \%$ of total revenues from excise duties in 2011), tobacco products (31\%), alcohol and beer (7,4\% of total revenues from excise duties in 2011) (Ministry of Finance Time Series Data, 2012).
} 
The level of harmonization of Croatian customs system with the acquis is very high, and only some minor changes in customs legislations are expected. The Croatian Customs tariff for 2011 has been aligned with the 2011 EU Combined Nomenclature. Some minor discrepancies still remain in the quota allocation system, inward/outward processing authorization, end-use and the internal transit arrangements (European Commission, 2011c). However, upon accession to the EU Croatia will lose a significant part of customs revenues which it realizes with the EU Member States, due to free entrance to the common internal EU market, i.e. accession to the Customs Union. Customs Union means free movements of goods and services by the abolition of physical and technical borders between Croatia and the EU Member States. In other words, upon accession to the EU only commodities imported from countries outside the EU will be subject to custom duties. According to the Croatian Bureau of Statistics (CBS, 2012), in 2010 Croatia imported goods and services worth HRK 110 bn; HRK 66 bn (60\%) of imports were from the EU Member States. In 2011 the level of imports increased to HRK 121 bn, HRK 75 bn (62\%) of them coming from the EU Member States (CBS, 2012). With the assumption that a similar ratio of imports from the EU Member States will be retained in $2013(60 \%)$, in the second part of the year 2013 only $40 \%$ of imports will be subject to custom duties, and of these $75 \%$ of the revenue will be transferred to the EU budget as Traditional Own Resources of the EU budget. Resulting from increased imports in 2011, the share of customs revenue also increased from $0.49 \%$ of GDP in 2010 to $0.52 \%$ of GDP in 2011 (Ministry of Finance Time Series Data). With the assumption that the ratio of customs revenue to GDP will be maintained at $0.5 \%$ in 2013 , it can be expected that there will be a reduction of customs revenue in a total amount of approximately $0.225 \%$ of GDP, which is calculated by the following expression:

$$
\frac{0.5 \%}{2} \cdot 60 \%+\frac{0.5 \%}{2} \cdot(1-60 \%) \cdot 75 \%=0.225 \% G D P
$$

Since the above stated conditions will be in place only in the second part of the year 2013 when Croatia becomes a formal EU Member State, both of these addends from expression (1) have to be divided by 2 in order to recalibrate the calculation to a semi-annual level. The first addend in the expression above amounts to $0.15 \%$ of GDP and shows the loss of budget revenue in the second part of the year 2013 as a result of the abolition of customs in the internal EU market, by which $60 \%$ of semi-annual customs revenue will be automatically lost upon Croatian accession to the EU due to trade in goods with the EU Member States. The second addend in the total amount of $0.075 \%$ of GDP shows Traditional Own Resources of the EU budget, i.e. the remaining part of $40 \%$ of semi-annual customs revenue will be distributed to the EU and Croatian budget in the proportion of 3:1. According to predefined keys, $75 \%$ ( $0.075 \%$ of GDP) of semi-annual imports subject to customs will be transferred to the EU budget, while the remaining part of $25 \%$ $(0.025 \%$ of GDP) will be kept in the Croatian budget. 
It is very important to emphasize that upon the accession of Croatia to the EU all free trade agreements with third countries that Croatia signed independently will cease to apply, including the Central European Free Trade Agreement (CEFTA). This will almost certainly have a specific repercussion on conditions of trade in goods, primarily in the regional context, with unfavorable effects on the Croatian trade balance. At the same time, upon accession to the EU, Croatia will be obliged to apply all agreements that current EU Member States have signed with third countries or with international organizations.

Upon accession of Croatia to the EU, in 2013 some funds will be transferred on the basis of VAT from the Croatian budget to the EU budget according to the applied rate of $0.3 \%$ on the VAT base or $50 \%$ of Croatian GNI. According to the data of European Commission (2007a), the Croatian VAT base is estimated at $57 \%$ of GNI, meaning that for the purpose of the calculation of VAT-based revenue a rate of $0.3 \%$ will be applied to the amount equal to $50 \%$ of GNI. According to Eurostat projections, the share of GDP in GNI in 2013 should amount to approximately 1.05 (calculated based on Eurostat database). Therefore, Croatian contribution to the EU budget on the basis of VAT would amount to somewhere in the region of $0.08 \%$ of GDP in 2013 , which is derived from the following calculation:

$$
\frac{0.3 \cdot 50 \% \cdot 1.05}{2}=0.08 \% G D P
$$

The first two members of the product in the numerator represent the application of the rate of $0.3 \%$ on $50 \%$ of GNI and the third member of the product in the numerator represents the ratio of GDP to GNI. The whole represents the calculated annual amount of VAT-based revenue from the Croatian budget as a share of GDP. Since Croatia will be EU Member State only in the second part of 2013, the above amount from the numerator has to be divided by 2 in order to get a semi-annual figure.

Total annual revenue of the EU budget on the basis of GNI amounted to about $0.75 \%$ of GNI of all EU Member States in 2010 (European Commission, 2011a). For the purpose of the estimation of expenditure from the Croatian budget on this basis in 2013, an unchanged annual share of $0.75 \%$ of GNI at the level of the whole EU budget will be assumed. The total amount of Croatian expenditures based on GNI in 2013 is derived from the following expression and it amounts to $0.36 \%$ of GDP.

$$
\frac{0.75 \% \cdot\left(G N I_{E U-27}+\frac{1}{2} G N I_{H R}\right) \cdot \frac{\frac{1}{2} G N I_{H R}}{G N I_{E U-27}+\frac{1}{2} G N I_{H R}}}{G D P_{H R}}=0.36 \% G D P
$$

All GDP and GNI projected data for the year 2013 used in the calculation above are taken from the Eurostat database. Total GNI-based revenue of the EU budget 
in 2013 will comprise $0.75 \%$ of GNI of all 27 current EU Member States and half of the Croatian GNI projected for the year 2013 (since Croatia will be EU Member State only in the second part of 2013). The absolute amount of total expenditure from the Croatian budget on the basis of the GNI in 2013 is calculated by multiplication of total VAT-based revenue of the EU budget (first two members of the product in the numerator) and the share of Croatian semi-annual GNI in the total GNI base, where total GNI base represents EU-27 total annual GNI enlarged by the Croatian semi-annual GNI. For the final figure, i.e. relative amount of total expenditure from the Croatian budget on the basis of the GNI in 2013, it is necessary to divide the absolute amount by the projection of the Croatian GDP for the year 2013 .

Average annual expenditure of the New Member States for the UK correction in the period from 2005 to 2010 amounted to $0.068 \%$ of the GDP (European Commission, 2011b). The same annual share in GDP will be assumed also in the projection for 2013, which means that Croatian contribution for the UK correction on a semi-annual basis would amount to $0.034 \%$ of GDP.

\section{TABLE 2}

Financial package from the EU for Croatia in 2013 (in million euro and $\%$ of $G D P$ )

\begin{tabular}{|c|c|c|c|c|}
\hline & \multicolumn{2}{|c|}{$\begin{array}{l}\text { Commitment } \\
\text { appropriations }\end{array}$} & \multicolumn{2}{|c|}{$\begin{array}{c}\text { Payment } \\
\text { appropriations }\end{array}$} \\
\hline & $\begin{array}{l}\text { Million } \\
\text { euro }\end{array}$ & $\%$ GDP & $\begin{array}{l}\text { Million } \\
\text { euro }\end{array}$ & $\%$ GDP \\
\hline 1 Sustainable Growth $(1 \mathrm{a}+1 \mathrm{~b})$ & 496.8 & 1.04 & 167.4 & 0.35 \\
\hline $\begin{array}{l}\text { 1a Competitiveness for } \\
\text { Growth and Employment }\end{array}$ & 47.4 & 0.10 & 17.6 & 0.04 \\
\hline $\begin{array}{l}\text { 1b Cohesion for Growth } \\
\text { and Employment }\end{array}$ & 449.4 & 0.94 & 149.8 & 0.31 \\
\hline of which Structural Funds & 299.6 & 0.63 & 89.9 & 0.19 \\
\hline of which Cohesion Fund & 149.8 & 0.31 & 59.9 & 0.13 \\
\hline $\begin{array}{l}2 \text { Preservation and Management } \\
\text { of Natural Resources }\end{array}$ & 20.4 & 0.04 & 12.1 & 0.03 \\
\hline $\begin{array}{l}\text { of which market related } \\
\text { expenditure and direct payments }\end{array}$ & 9.0 & 0.02 & 9.0 & 0.02 \\
\hline 3 Citizenship, freedom, security and justice & 73.3 & 0.15 & 42.2 & 0.09 \\
\hline $4 \mathrm{EU}$ as a global player & 0.0 & 0.00 & 77.6 & 0.16 \\
\hline 5 Administration & 22.0 & 0.05 & 22.0 & 0.05 \\
\hline 6 Compensations (Cash-flow facility) & 75.0 & 0.16 & 75.0 & 0.16 \\
\hline Total & 687.5 & 1.44 & 396.3 & 0.83 \\
\hline
\end{tabular}

Source: European Commission (2012); author's adjustment.

Upon entering the EU, Croatia will have to provide a certain amount for equity and reserves contribution for the European Investment Bank (EIB). Cuculić, 
Faulend and Šošić (2004) estimated that amount to $0.03 \%$ of GDP, which is also in accordance with the payment of almost all New Member States in the first year of their membership (Money-Go-Round.eu database) ${ }^{8}$.

However, apart from the already mentioned categories of expenditures that will be transferred to the EU budget, the Croatian budget will also benefit from EU membership, manifested in the form of a various transfers from the EU budget. In May 2012 the European Commission published a document as a preparation for the 2013 Draft Budget (European Commission, 2012) including also the whole proposal of a Croatia financial package for the semi-annual period of the EU membership. The main proposed budgeted categories of expenditures from the EU budget allocated to the Croatian budget, i.e. potential revenues of Croatian budget, are shown in table 2 .

According to the data from table 2, in 2013 Croatia should receive overall financial funds in total amount of EUR $396 \mathrm{~m}$ from the EU, i.e. equivalently $0.83 \%$ of GDP. The major share of these funds in amount of EUR $167 \mathrm{~m}(0.35 \%$ of GDP) relates to category Sustainable Growth, including the subcategories Competitiveness for Growth and Employment and Cohesion for Growth and Employment. Funds dependant on projects amount to total EUR $159 \mathrm{~m}(0.33 \%$ of GDP $)$ and include funds from Structural Funds in amount of EUR $90 \mathrm{~m}(0.19 \%$ of GDP), funds from the Cohesion Fund in amount of EUR $60 \mathrm{~m}(0.13 \%$ of GDP) and market related expenditures amounting to around EUR $9 \mathrm{~m}(0.02 \%$ of GDP). Unlike payment appropriations including expected financial funds that should be paid to Croatia in 2013, commitment appropriations comprise total amount of all activities that should be executed, i.e. invoiced during 2013. Total amount of commitment appropriations should amount to EUR $687.5 \mathrm{~m}$ or $1.44 \%$ of GDP, which is about $73 \%$ more than expected payment appropriations. The category EU as a global player does not include commitment appropriations, while payment appropriations are included in the draft budget and amount to EUR $77.6 \mathrm{~m}$. The reason beyond is that upon accession of Croatia to the EU, funds aimed at external policies will no longer be allocated to Croatia, instead financing of Croatia will become a part of the EU internal policies. Hence in 2013 there will be no new contracted payments from pre-accession funds, but there should be payments for projects contracted in some earlier period, which is visible in the payment appropriations item.

Table 2 does not include direct payments for which the sum of EUR $93.2 \mathrm{~m}$ is provided in 2013, according to the data of the Ministry of Finance (2012). These funds will be paid in 2014 for liabilities towards farmers per hectare of eligible area relevant in 2013. According to the data of the Ministry of Finance (2012) the total financial envelope for the first half year of the EU membership should amount

\footnotetext{
${ }^{8}$ Among all observed countries (NMS-8), only Poland paid in $0.04 \%$ of GDP for EIB in 2004, while all other countries paid in $0.03 \%$ of their GDP.
} 
to around EUR $800 \mathrm{~m}$. Apart from the already mentioned commitment appropriations items that were presented in table 2 and that are dependent on different project activities, the envelope is also composed of the following funds:

- Schengen - external borders strengthening (EUR $40 \mathrm{~m}$ );

- Reinforcement of institutions (EUR $29 \mathrm{~m}$ );

- Demining (EUR 2.4 m);

- Supports to the budget in strengthening the financial position (EUR $75 \mathrm{~m}$ );

- Costs of administration in Brussels (EUR $22 \mathrm{~m}$ );

- Participation in different EU programs - Seventh Framework Programme for Research, longlife learning, Erasmus Mundus, Trans-European Network for energy and transport (TEN-E and TEN-T; all together EUR 47.4 m).

In order to receive the allocated funds from the Structural Funds, Cohesion Fund and Rural Development Funds, the Croatian primary task is to establish adequate administrative absorption capacities and to prepare adequate project activities. Moreover, it is necessary to ensure funds for co-financing of projects at the state and local level, which will definitely represent an additional burden on the Croatian budget. The minimum prescribed co-financing rate of a Member State corresponds to $25 \%$ of total funds from the Structural Funds and Rural Development Funds and $15 \%$ of total funds from the Cohesion Fund. On the other hand, the EU has historically co-financed projects to the extent of between 50 and $85 \%$ (The European Bank Coordination ("Vienna") Initiative, 2011), while the financing of the remaining part up to the total project value was the responsibility of the Member State in question.

From the amounts planned for financing from the EU budget, as shown in table 2, it is quite easy to derive the amount of funds that should be secured by a Member State itself (in this case Croatia) for projects co-financing. This amount depends on the applied rate of Member State co-financing and can be expressed with the following formula:

$$
R_{i}^{M S}=R_{i}^{E U} \cdot \frac{r_{i}}{1-r_{i}}
$$

where $R_{i}^{E U}$ represents the amount of funds for projects financing from the EU budget and $r_{i}$ is the average applied co-financing rate of the Member State itself. Index $i$ denotes a general category for co-financing, i.e. Structural Funds, Cohesion Fund or Rural Development Funds.

From the calculation derived from the application of the equation (4) it can be concluded that Croatia will have to provide financial resources of approximately $0.09 \%$ of GDP for co-financing projects under the assumption of the application of the minimum co-financing rate $(25 \%$ of total funds from the Structural Funds and Rural Development Funds and 15\% of total funds from the Cohesion Fund), i.e. $0.15 \%$ of GDP in the case of the application of the co-financing rate amounting 
to 10 percentage points higher than the minimum prescribed (35\% of total funds from the Structural Funds and Rural Development Funds and 25\% of total funds from the Cohesion Fund).

\section{TABle 3}

Net position of Croatia in the EU budget and financial costs/benefits of accession in 2013 (\% of GDP and in million euro)

\begin{tabular}{|c|c|c|}
\hline Revenue/expenditure category & $\%$ GDP & Million euro \\
\hline 1 Payments from the EU budget & 0.83 & 396.30 \\
\hline Structural Funds & 0.19 & 89.90 \\
\hline Cohesion Fund & 0.13 & 59.90 \\
\hline $\begin{array}{l}\text { Market related expenditure and direct } \\
\text { payments of the EU budget }\end{array}$ & 0.02 & 9.00 \\
\hline Other resources of the EU budget & 0.50 & 237.50 \\
\hline 2 Payments into the EU budget & 0.55 & 260.33 \\
\hline Traditional own resources & 0.08 & 35.81 \\
\hline VAT-based own resources & 0.08 & 37.56 \\
\hline GNI-based own resources & 0.36 & 170.66 \\
\hline UK correction & 0.03 & 16.30 \\
\hline 3 Other costs/benefits $(-/+)$ & -0.13 & -63.67 \\
\hline EIB contribution (-) & 0.03 & 14.32 \\
\hline Free trades with the EU (-) & 0.15 & 71.61 \\
\hline Projects co-financing - average rates (-) & 0.15 & 73.22 \\
\hline Projects co-financing - minimum rates & 0.09 & 43.54 \\
\hline Abolishment of VAT zero rates $(+)$ & 0.20 & 95.49 \\
\hline Costs of institutions and reforms (-) & ? & ? \\
\hline Net position of Croatia in the EU budget (1-2) & 0.28 & 135.97 \\
\hline Financial costs/benefits of accession (1-2-3) & 0.15 & 72.29 \\
\hline
\end{tabular}

Source: Author's calculation.

From the calculation explained in the previous part of the text and presented in table 3 it is shown that Croatia should benefit in a financial way from the EU membership in 2013. The Croatian net position in the EU budget in 2013 shows that Croatia, just like all New Member States, should be a net recipient, in which the anticipated Croatian net position in the EU budget is equal to $0.28 \%$ of GDP, i.e. EUR $136 \mathrm{~m}^{\text {in absolute terms }}{ }^{9}$. Furthermore, the total net financial position of Croatia due to accession to the EU in 2013 should amount to approximately $0.15 \%$ of GDP, i.e. around EUR $72 \mathrm{~m}$.

It is important to stress that figures from table 3 can be correctly interpreted exclusively with assumption that all funds from the EU budget shown in table 2 flow directly into the general government budget, i.e. assuming all funds from the EU funds are used by the public sector. The implicitly contained assumption in the

\footnotetext{
${ }^{9}$ Nominal amount is calculated by multiplication of estimated effect (as a percent of GDP) with projection of GDP for 2013 (Eurostat database).
} 
calculations is that all of these funds truly create the effect of substitution, i.e. they replace national financing in certain areas. Otherwise, the level of national funding would remain the same, while some funds from the EU budget would be an additional source of funds for projects and grants, but also an additional pressure on the budget.

Moreover, there is also a part of expenditure that is almost impossible to assess, since there are no publicly available data on the costs of building institutions and their maintenance, as well as costs of execution of reforms, so this is left out of the analysis. However, the cost of institutions involved in implementation of EU programs is already included in the Croatian budget, since the institutional framework for using the EU funds is mainly the continuation of a structure that is involved in the implementation of the pre-accession program (Ministry of Finance, 2010). Thus, these effects should not have any impact on this analysis.

\section{CROATIAN BUDGET PERSPECTIVE IN THE PERIOD UP TO 2020}

After accession to the EU, EU funds will be targeted to strengthening transport infrastructure (especially in the field of railway transport), water management, projects of centres for waste management, the energy sector, connecting science and the economy and business infrastructure. Special attention is also dedicated to the labour market, high-quality employment and social inclusion, promotion and execution of lifelong learning programmes and prequalifications in order to develop a flexible and competitive labour force (Ministry of Finance, 2012).

Real effects after 2013 are impossible to estimate adequately, since a large part of EU budget revenues and expenditures is still under special attention and it is currently considered an optimal model of financing and implementation. Still, for the purpose of the estimation of future expected net financial flows from the EU budget, experiences of the EU New Member States can be definitely helpful. In this context, the New Member States (NMS) comprise 8 countries that have been EU Members since 1 May 2004, and these are the Czech Republic, Estonia, Latvia, Lithuania, Hungary, Poland, Slovakia and Slovenia. These countries are especially interesting in this analysis since they entered the EU in the middle of the year, as Croatia should, and they are also connected to Croatia by a common geographical, political and social background.

Funds from the Structural Funds and the Cohesion Fund are available to regions, i.e. countries with GDP per capita lower than a specific percentage of the EU average. In the case of the Structural Funds and the Cohesion Fund this percentage is $75 \%$, while a special arrangement of transition regions funds within Cohesion Policy is available to countries with a per capita GDP between $75 \%$ and $90 \%$ of the European average. According to Eurostat data, in 2010, Croatian GDP per capita equalled $61 \%$ of the EU average, which means that in the following period Croatia will be a candidate for receiving funds from the Structural Funds and the 


\section{Figure 5}

GDP per capita measured by purchasing power standard expressed as an average of EU-27 in the period 1995-2010
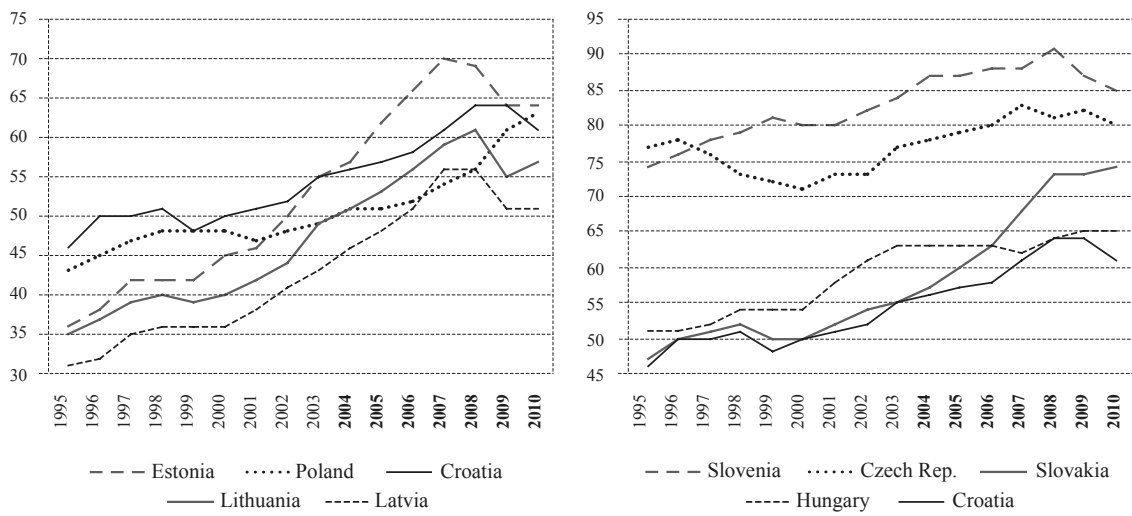

Source: Author's calculation.

In the whole period 1995-2010 all New Member States and Croatia were below the all 27 EU Member States average, but they recorded GDP per capita growth comparable to the EU-27 average ${ }^{10}$. Generally, it can be concluded that countries with higher initial GDP per capita have recorded slower growth and vice versa, a phenomenon known as real convergence ${ }^{11}$. A slower growth trend than Croatia in the observed period was recorded only by Slovenia, which had significantly higher GDP per capita in 1995 (74\% of the EU-27 average), and by Poland and Hungary, which had relatively similar levels of GDP per capita in 1995 as Croatia (Hungary $51 \%$, and Poland $43 \%$ of the EU-27 average) ${ }^{12}$. Therefore, it can be assumed that the pre-accession phase, together with EU membership, has had a certain impact on the stimulation of the economic activity growth. With the optimistic assumption of medium term growth as in the period from 2000 to 2010 (growth from $50 \%$ to $61 \%$ of the EU-27 average, i.e. 22\%), Croatia may reach in 2020 the level of $74.4 \%$ of the EU-27 average GDP per capita in PPS, which means that it would come close to the transition countries threshold. Still, in view of current economic conditions, it is highly unlikely that in the following period up to 2020 Croatia could manage to record real economic activity growth as it did in

\footnotetext{
${ }^{10}$ EU-27 average is denoted with 100, and it is calculated retroactively for the whole period 1995-2004 such that includes average of all 27 current Member States, although some of them were not members of the EU in that time.

${ }^{11}$ For more details on real convergence in the EU see for instance Vojinović and Oplotnik (2008), Halmai and Vásáry (2010), Kulhánek (2012) and European Commission (2009:33-34).

${ }^{12}$ Growth trend in this case means a slope (regression coefficient) of a linear regression line of a specific country.
} 
the pre-crisis period. Hence a more realistic scenario estimates much lower growth of GDP per capita to $63 \%$ of the EU-27 average in $2020^{13}$.

\subsection{NEW MEMBER STATES' EXPERIENCES IN THE FIRST YEARS OF THE EU MEMBERSHIP}

The following text will show an analysis of the budget revenue of New Member States in the period 2004-2010, which will later on be used in an estimation of the Croatian potential. Figure 6 shows the budget revenue of New Member States on the basis of Structural Funds, as a percentage of GDP.

\section{Figure 6}

Revenue from Structural Funds to New Member States (\% of GDP)
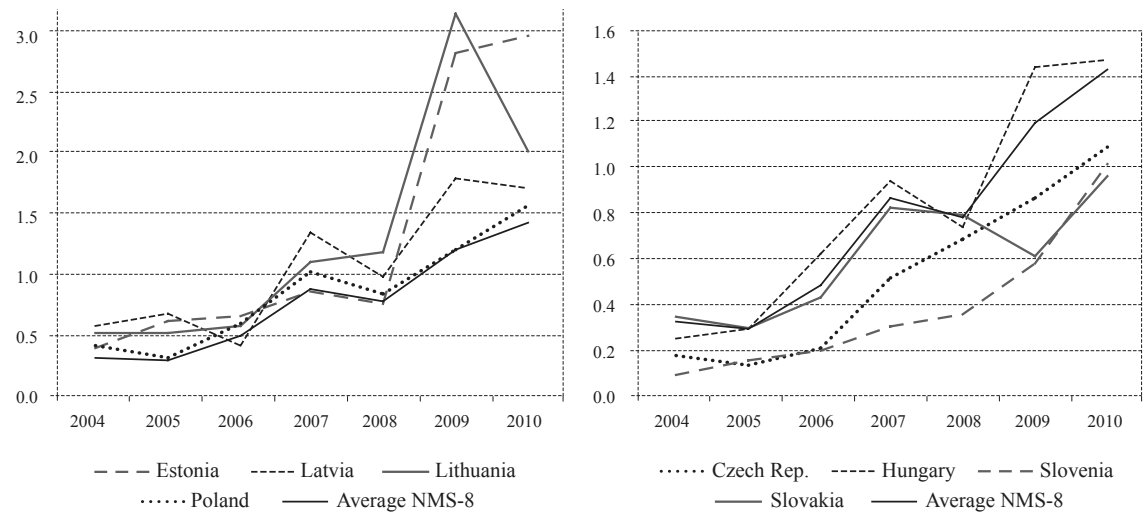

Source: Author's calculation.

The New Member States average shows a clear trend of revenue growth on the basis of the Structural Funds from the moment of accession to the EU in 2004 up to 2010. Expectedly, in the first years of EU membership, the share of the funds amounts to less than $0.5 \%$ of GDP due to implementation of starting project activities and development of absorption capacities. In the seventh year of EU membership, i.e. in 2010, the average share of revenue from the Structural Funds reached almost $1.5 \%$ of GDP. It is interesting to notice Lithuania in 2009 and Estonia in 2010 since these two NMS managed to withdraw funds in the total amount of around $3 \%$ of GDP.

\footnotetext{
${ }^{13}$ Calculated by using actual Croatian GDP growth estimates for the years 2012 and 2013 available from public press release of the Institute of Economics, Zagreb (2012) in which it is estimated that the Croatian real GDP growth rate was $-1.3 \%$ in 2012 and will be $0.8 \%$ in 2013 . For further projections, as well as for projections of average GDP growth rates of EU countries, IMF forecasts were used (IMF, 2012a; 2012b). For the sake of simplification of calculation of GDP per capita, it is assumed that the number of inhabitants in Croatia and the EU will not change significantly.
} 
Figure 7

Revenue from Cohesion Fund to New Member States (\% of GDP)

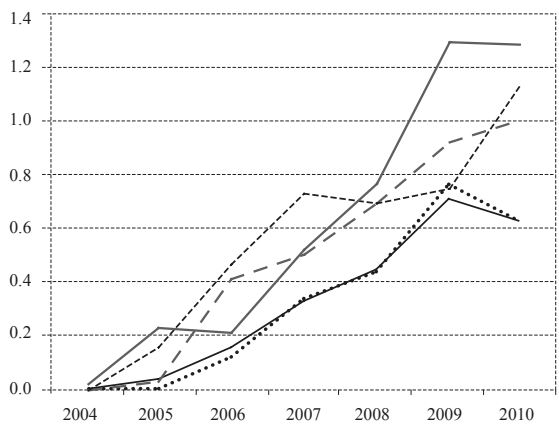

- - - Estonia ----- Latvia Lithuania

..... Poland Average NMS-8

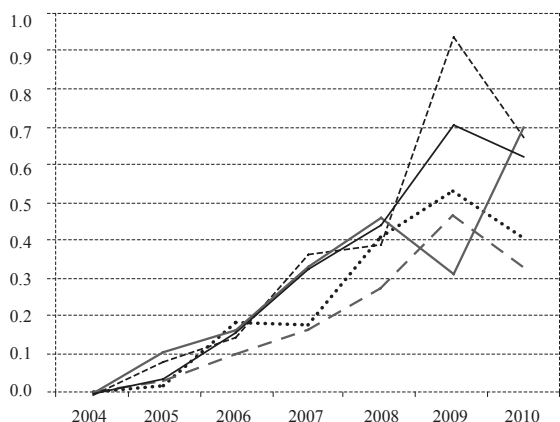

…. Czech Rep. ----- Hungary - - - Slovenia

Source: Author's calculation.

As in the case of the Structural Funds, all New Member States satisfied the criteria for getting funds from the Cohesion Fund. Since the Cohesion Fund is also project-oriented, funds that a certain Member State manages to withdraw from the EU budget depend on projects and it is quite reasonable that the amount of funds withdrawn will gradually increase year by year as the absorption capacities are built. In the first two years of EU membership the amount of funds paid from the Cohesion Fund to NMS is almost negligible, while after these two years gradually increases year by year in the average amount of $0.1-0.2 \%$ of GDP. In the whole observed period from 2004 to 2010 Lithuania managed to withdraw the highest share of funds in GDP in 2009 and 2010 amounting to approximately 1.3\% of GDP.

\section{Figure 8}

Revenue from Rural Development Funds to New Member States (\% of GDP)
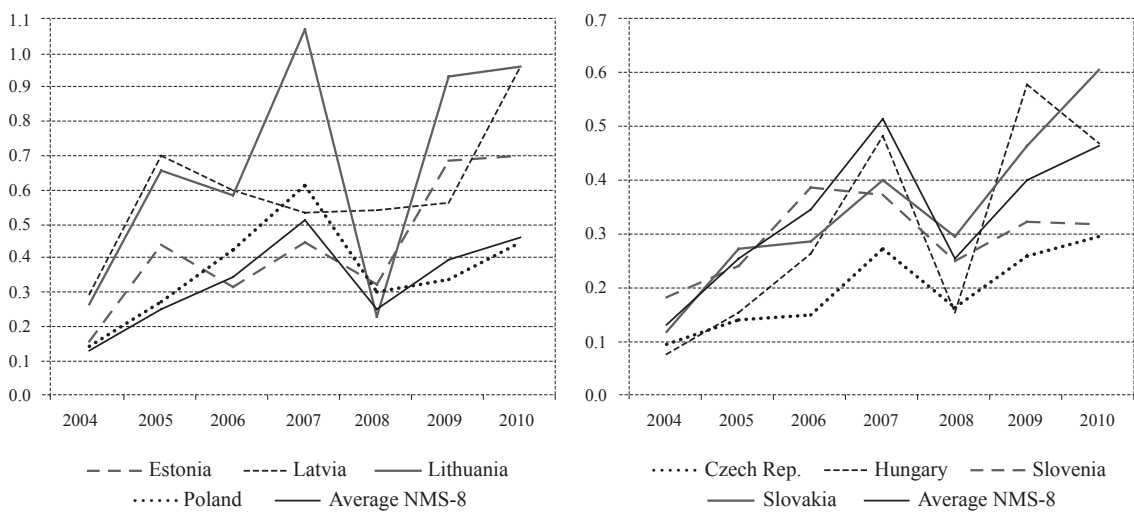

Source: Author's calculation. 
Rural Development Funds paid to New Member States show a less obvious trend in the observed period 2004-2010. Nevertheless, as in the case of the Structural Funds and the Cohesion Fund, the lowest paid amount of funds was recorded in the first year of EU membership, i.e. in 2004, and afterwards increased. The highest average paid amount was recorded in 2007 and amounts to $0.51 \%$ of GDP. In case of Rural Development Funds Lithuania also managed to withdraw the highest share of funds with regard to the size of GDP in 2007 amounting to $1.07 \%$ of GDP.

\section{Figure 9}

Direct aids in agriculture to New Member States (\% of GDP)
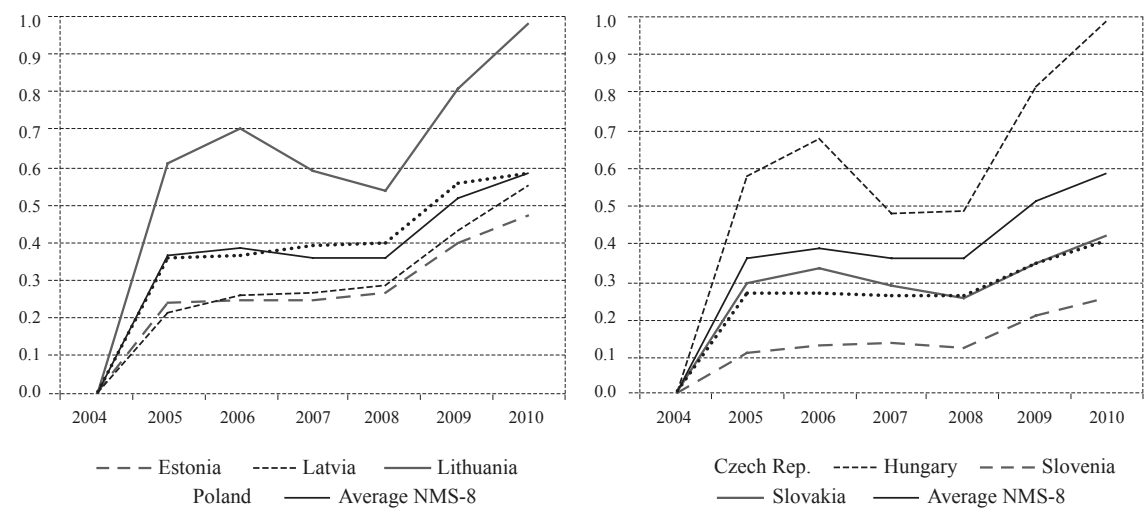

Source: Author's calculation.

Direct aids in agriculture were paid to New Member States for the first time in 2005. Cuculić, Faulend and Šošić (2004) pointed out that payments of individual grants are delayed by about three months, which transfers payments into the next fiscal year, producing what is called the liquidity gap. In the period from 2005 to 2008 the average share of direct aids in agriculture in GDP was kept at similar levels (averagely $0.37 \%$ of GDP), but it increased in 2009 to $0.52 \%$ of GDP and in 2010 to $0.58 \%$ of GDP.

As mentioned above, the Cohesion Policy comprises the Structural Funds and the Cohesion Fund, while Natural Resources Policy comprises funds within the Common Agricultural Policy. Figure 10 shows the share of paid and allocated funds to New Member States in the period 2007-2010 divided into these two categories.

Figure 10 clearly shows a growth trend in utilized funds in the observed period in the Cohesion Policy category, which increased from an average of $47.2 \%$ in 2007 to 73.6 in 2010. Among Member States there were significant differences by categories, which is indicated by the standard deviation, amounting to 31 percentage points in 2009. Shares of paid funds with regard to allocated funds to NMS are 
generally higher in the Natural Resources category. However, in this category there is no obvious trend of an increase in utilization as there is in the case of Cohesion for Growth and Employment. It is important to emphasize that between allocations and payments there is a certain time gap in cash flows. That is, the allocated funds connote commitment appropriations and relate exclusively to funds available for contracting in the current year. On the other hand, paid funds connote payment appropriations, i.e. relate to funds contracted in the current year, but also to those contracted in the past years, which are payable in the current year.

\section{Figure 10}

\section{Share of paid and allocated funds to New Member States in 2007-2010 (\%)}

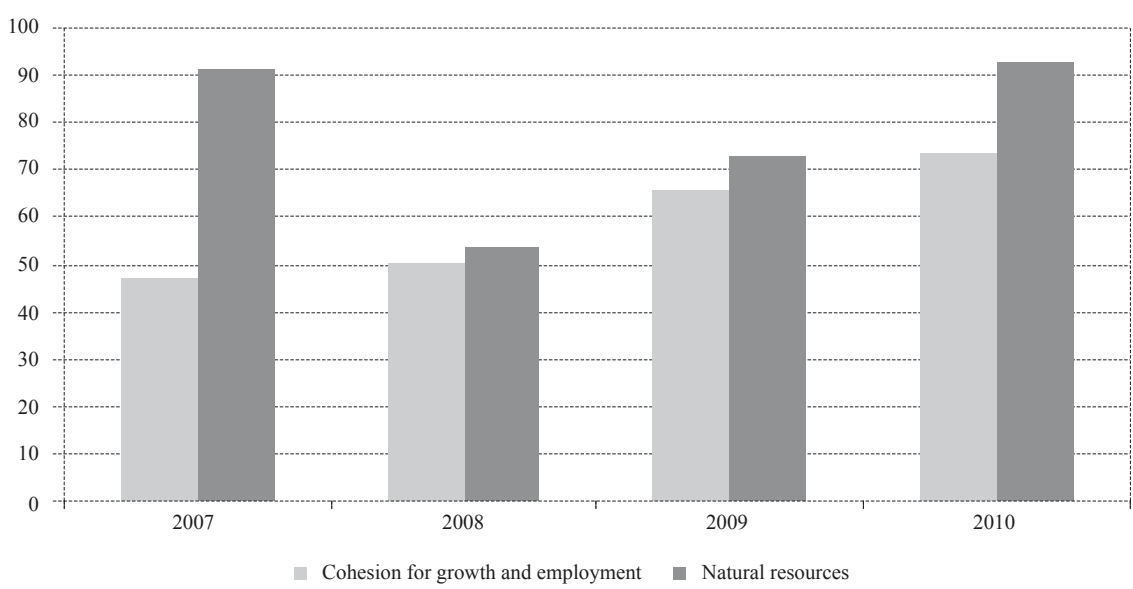

Source: Author's calculation based on European Commission (2007b; 2007c; 2011b).

Other revenues of Member States are somehow related also to the period before formal EU membership, since this category includes mainly pre-accession assistance, but also special arrangements and budgetary compensations. These revenues of New Member States show a clear growth trend up to 2004, which is the period including numerous preparations for institution development and administration, and for the purpose of building absorption capacities. In the period from 2004 to 2007 the average share of other revenue from the EU budget to NMS recorded a sharp decrease, primarily due to a decline in residual cash flows for contracted projects covered by the pre-accession funds. In the period after 2007 this share was kept at a stable level of about $0.15 \%$ of GDP.

Generally, it is very important to stress that not all countries have the same possibilities of funds withdrawal, as measured by the share of their GDP. The reason is that some Member States have relatively higher, while on the other hand some of them have relatively lower allocations in the EU funds. According to data from European Commission (2007b; 2007c), calculated average of allocated funds for categories Cohesion for Growth and Employment and Rural Development for 
New Member States in the period 2007-2010 amounts to 3.2\% of GDP, but the highest proportions of funds relative to the size of GDP were allocated to Hungary (4.0\%), Lithuania (3.9\%) and Latvia (3.7\%). Lithuania generally has the highest proportions of received funds in the observed period 2004-2010, which can be mainly explained by higher allocated funds. IMF (2006) stresses that in the period from 2004 to 2006 approved funds from the EU funds to Lithuania amounted on average to $5.4 \%$ of GDP per annum, which is the highest share of funds in GDP among all New Member States. Latvia had a similar share in GDP, while all other Member States had over one percentage point lower approved amounts from the EU funds as a percentage of GDP.

\section{Figure 11}

Other revenue from the EU budget to New Member States (\% of GDP)
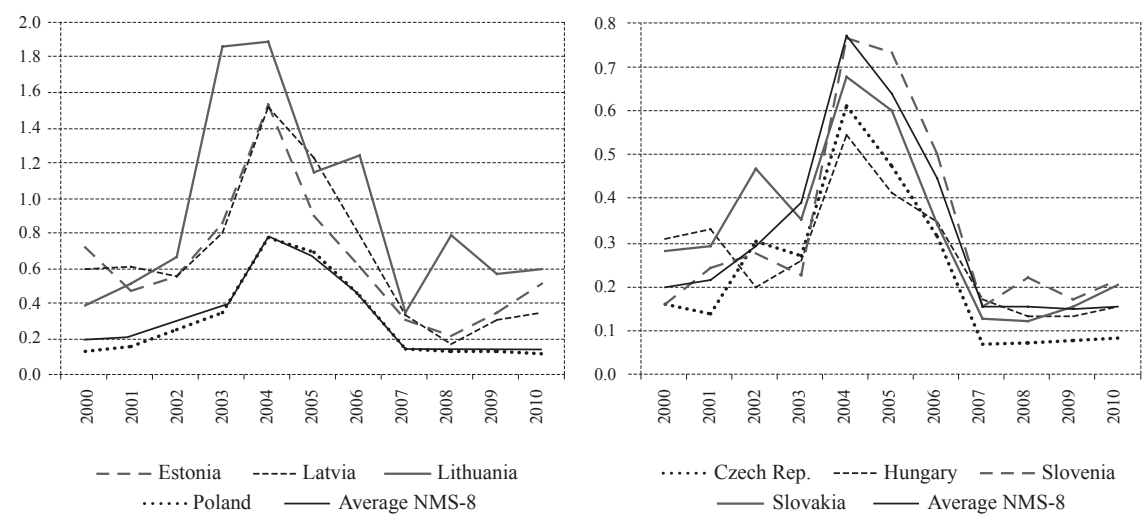

Source: Author's calculation.

\subsection{CROATIAN POTENTIAL IN THE EU FINANCIAL PERSPECTIVE FROM 2014 TO 2020}

New Member States experiences examined in the previous part of the paper can serve as a good background for the estimation of the Croatian potential in the period from 2014 to 2020 covered by the new EU financial perspective.

According to the Ministry of Finance (2012) data, from 2014 and onwards an annual amount of EUR 1.6 bn has been promised to Croatia from European funds used through the Cohesion Policy. The Rural Development Fund in 2013 will continue to be executed through IPARD and will amount to EUR $27.7 \mathrm{~m}$, while in the following years it should be significantly higher and amount to around EUR $330 \mathrm{~m}$. In the financial envelope it is stated that funds in 2014 will be 2.33 times higher than those allocated for 2013, and in 2015 approximately 3 times higher 
than those in $2013^{14}$. This means that in 2014 Croatia should have a disposable potential of around EUR 1.1 bn for using financing from the EU funds, in the categories Cohesion Policy and Common Agricultural Policy. This amount should rise to EUR 1.4 bn in the period 2015-2020. However, here it is very important to stress two things. First, the new financial perspective is still not adopted, so these amounts promised to Croatia may be considered only as a possibility. Second, the total received funds from these sources will depend primarily on the capability of absorption of these funds, i.e. quality projects.

\section{Figure 12}

Allocated and paid funds from EU funds (in billion euro) and share of paid and allocated funds (in \%), period 2014-2020

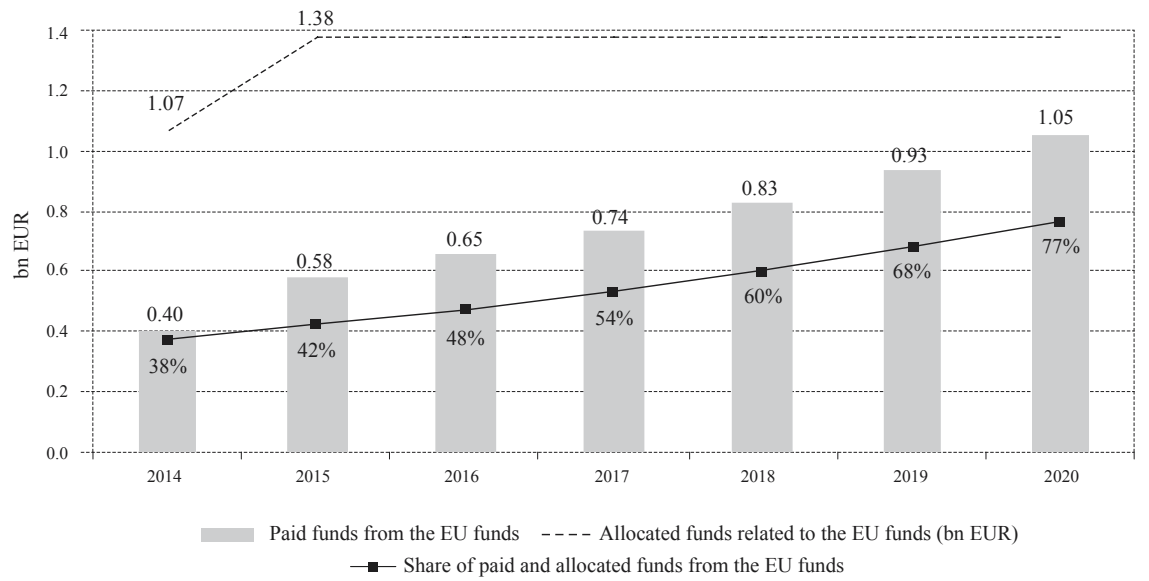

Source: Author's calculation.

Based on average shares of paid and allocated funds in the case of the New Member States (figure 10) gradual and stable growth of payments from the EU funds to Croatia in the whole period from 2014-2020 can be assumed. From table 2 it is noticeable that the expected proportion of paid and allocated funds for the items Cohesion Policy and Common Agricultural Policy should amount to 34.6\% in 2013. Assuming that Croatia will be recording linear growth from $34.6 \%$ in 2013 to $76.5 \%$ in 2020 (where $76.5 \%$ represents a weighted average of Cohesion Policy and Common Agricultural Policy of New Member States in 2010 from figure 10) and with the assumption of allocated funds of EUR 1.1 bn in 2014 and EUR 1.4 bn per annum in the whole period 2015-2020, it can be concluded that Croatia

\footnotetext{
${ }^{14}$ Financial envelope means the amount of funds that a candidate country manages to ensure during the negotiating process and which will be available to this country after obtaining full membership status in the European Union. In case of Croatia a gradual increase of funds has been negotiated (the so called phase-in period), by which in the first one year period (1 July 2013 - 30 June 2014) Croatia would be entitled to $60 \%$ of its normal allocations, in the next one year period (1 July 2014 - 30 June 2015) $80 \%$ and after 1 July $2015100 \%$ of its normal allocations (Ministry of Foreign and European Affairs, 2011). Additionally, total allocated funds in 2013 will be significantly lower due to semi-annual membership.
} 
could withdraw funds from the EU budget related to the EU funds in the total amount of EUR 5.2 bn in the new financial perspective 2014-2020. Thereby this amount continuously increases amounting to EUR 0.4 bn in 2014, EUR 0.6 bn in 2015 up to EUR 1.1 bn in 2020. Projections of allocated and paid funds from the EU funds, as well as the share of paid and allocated funds in the period 2014-2020 are shown on figure 12.

According to the data from table 2, Croatia could count on other revenue from the EU budget in the amount of EUR $237.5 \mathrm{~m}$ in 2013, i.e. $0.49 \%$ of GDP. Following the same dynamics of other revenues from the EU budget as in the figure 11, it can be concluded that Croatia may receive funds amounting to $0.6 \%$ of GDP in 2014, $0.4 \%$ of GDP in 2015 and $0.2 \%$ of GDP in the whole following period up to 2020 . This would correspond to approximately EUR 1.15 bn for the whole period 20142020. Projection of total funds received from the EU budget in the period 20142020 is shown in table 4.

TABLE 4

Projections of funds received from the EU budget in the period 2014-2020 (\% of GDP and in billion euro)

\begin{tabular}{|c|c|c|c|c|c|c|c|c|}
\hline & 2014 & 2015 & 2016 & 2017 & 2018 & 2019 & 2020 & $\begin{array}{c}\text { Total } \\
2014-20\end{array}$ \\
\hline $\begin{array}{l}1 \text { Allocated funds related } \\
\text { to EU funds (EUR bn) }\end{array}$ & 1.07 & 1.38 & 1.38 & 1.38 & 1.38 & 1.38 & 1.38 & 9.32 \\
\hline $\begin{array}{l}2 \text { Share of paid and } \\
\text { allocated funds from } \\
\text { the EU funds }(\%)\end{array}$ & 37.53 & 42.26 & 47.59 & 53.59 & 60.34 & 67.94 & 76.50 & 55.69 \\
\hline $\begin{array}{l}3 \text { Paid funds from } \\
\text { the EU funds }(1 * 2)\end{array}$ & 0.40 & 0.58 & 0.65 & 0.74 & 0.83 & 0.93 & 1.05 & 5.19 \\
\hline $\begin{array}{l}4 \text { Other revenues from } \\
\text { the EU budget (EUR bn) }\end{array}$ & 0.30 & 0.21 & 0.11 & 0.12 & 0.13 & 0.14 & 0.15 & 1.15 \\
\hline Total $(3+4)$ & 0.70 & 0.79 & 0.77 & 0.86 & 0.96 & 1.07 & 1.20 & 6.34 \\
\hline
\end{tabular}

Source: Author's calculation.

Total estimated amount of all funds that Croatia may receive from the EU budget in the period from 2014 to 2020 amounts to EUR 6.34 bn, whereby the annual amounts gradually increase year after year, starting from EUR 0.7 bn in 2014 to EUR 1.2 bn in 2020. It is also interesting to notice a slight decrease in total received funds from the EU budget in 2016, compared to 2015. The reason for this decrease lies in the fact that other revenue from the EU budget significantly decreases in the first years of EU membership primarily due to decreased payments agreed in the pre-accession period, while on the other hand utilized, i.e. received funds from the EU budget grow by slower dynamics. These two effects taken together led to this decline in projection for 2016. A rough estimate of the funds that Croatia could receive from the EU budget in the new financial perspective up to 
2020 may serve as an insight into possible perspective with numerous constraints mentioned in the previous text. Final realization will primarily depend on real allocated funds, built administrative and financial capacities, as well as quality projects activities.

Figure 13 shows net positions of all Member States in the EU budget with regard to their GDP per capita in 2010.

\section{Figure 13}

Scatter plot of operational balance of the EU budget and GDP per capita (in current prices) in all Member States, year 2010

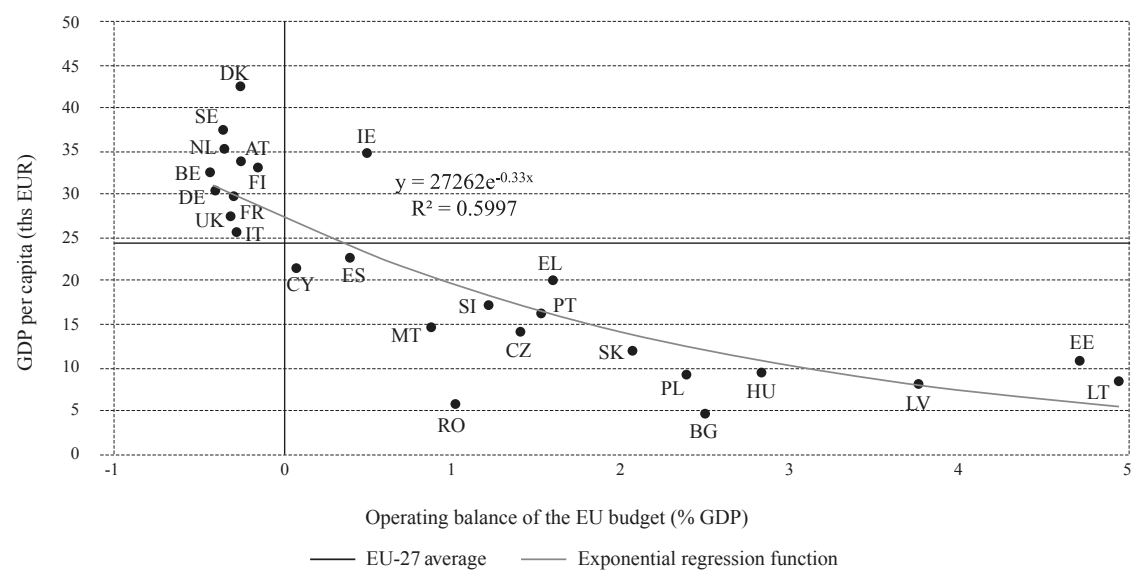

Source: Author's calculation.

Operational balance shows the net position of a certain Member State in the EU budget, i.e. the difference between payments into the EU budget and received funds from the EU budget. The scatter plot of the operational balance of the EU budget and GDP per capita (in current prices) of all Member States shows that there is a clear negative relationship between these two variables, meaning that Member States with higher GDP per capita generally record lower net financial positions with the EU budget and vice versa. For modelling this relationship an exponential function was shown as the best choice, since it fits realisations quite well, which is proven by the relatively high coefficient of determination $\left(R^{2}\right.$ statistics) of $60 \%$. Detailed statistics of the observed model, i.e. its transformation into the linear regression model, are displayed in table $5^{15}$. It is interesting to notice that all New Member States are net recipients of funds from the EU budget, this

\footnotetext{
${ }^{15}$ A simple transformation of an exponential model into a linear regression model was made. By taking a natural logarithm of an expression $y=\alpha e^{\beta x}$ a linear equation model expressed as $y^{\prime}=\alpha{ }^{\prime}+\beta x$ is derived, where $y^{\prime}=\log y$ and $\alpha^{\prime}=\log \alpha$. This means that there is a linear relationship between natural logarithm of GDP per capita measured by purchasing power standard and operational balance of the EU budget.
} 
amount varying from the lowest $1.2 \%$ of GDP in case of Slovenia to the highest $4.9 \%$ of GDP in case of Lithuania.

\section{TABLE 5}

Estimated parameters and representativeness indicators of linear regression model of GDP per capita (natural logarithm) and operational balance of the EU budget

\begin{tabular}{|c|c|}
\hline Variable & Estimate (t-statistics) ${ }^{\mathrm{a}}$ \\
\hline Intercept $(\alpha)$ & $\begin{array}{l}10.21323 \\
(100.45)^{* * *}\end{array}$ \\
\hline Regression coefficient $(\beta)$ & $\begin{array}{l}-0.3302 \\
(-6.12)^{* * *}\end{array}$ \\
\hline Representativeness indicators & Realization of sample \\
\hline Explained sum of squares (SSreg) & 7.16726 \\
\hline Residual sum of squares (SSerr) & 4.78345 \\
\hline Total sum of squares (SStot) & 11.95071 \\
\hline F-statistics & 37.46 \\
\hline p-value of F-statistics & $<0.0001$ \\
\hline Coefficient of variation & 4.43442 \\
\hline Coefficient of determination $\left(R^{2}\right)$ & 0.5997 \\
\hline Adjusted coefficient of determination (Adj. $R^{2}$ ) & 0.5837 \\
\hline
\end{tabular}

${ }^{a}$ Significance levels: $1 \% * * *, 5 \% * *$ and $10 \% *$.

Source: Author's calculation.

Assuming that the modelled relationship between GDP per capita and operational balance of the EU budget is generally in place, from familiar GDP per capita figure the approximate net position of Croatia in the EU budget in a certain year can be estimated. A projection of Croatian GDP per capita in current prices in 2020 amounts to EUR 15.445 and involves net receipts of funds from the EU budget in a total amount of $1.72 \%$ of GDP, i.e. EUR $1.13 \mathrm{bn}^{16}$. Still, it has to be emphasized that this estimation was made assuming the current system of financing the EU budget, which means that all the potential changes explained in chapter three of this paper could significantly modify the final result. Hence this estimate of the Croatian net position could be primarily understood as a Croatian potential in 2020, rather than a direct projection, since the final net position of Croatia in the EU budget will depend on a numerous set of variables impossible to assess fully qualitatively and quantitatively. Therefore all quantitative results given in the paper should be interpreted with special care.

\footnotetext{
${ }^{16}$ GDP forecast for 2020 was calculated from actual GDP growth and inflation rate estimations for 2012 and 2013 available in the press release of the Institute of Economics, Zagreb (2012), which provides an estimate of Croatian real GDP growth rate of $-1.3 \%$ in 2012 and $0.8 \%$ in 2013, as well as an inflation rate of $3.2 \%$ in 2012 and $2.6 \%$ in 2013. Furthermore, it is assumed that there will be a linear real GDP growth up to $2.5 \%$ in 2017 in accordance with IMF (2012a; 2012b) long term forecasts and stabilization of real GDP growth on the level of $2.5 \%$ up to 2020 . In the whole period 2014-2020 a stable inflation rate of $2.5 \%$ is assumed. Moreover, for the sake of simplification it is implicitly assumed that population sizes in Croatia and the EU in 2020 will remain the same as in 2013 .
} 
Accession of Croatia to the EU will bring numerous changes certain to impact net cash flows from the EU budget to Croatian budget and vice versa. In the second half of the year 2013 Croatia will be included in the still current financial perspective of the EU covering the period 2007-2013. According to estimation results presented in this paper Croatia should a record positive net financial position in the EU budget in a total amount of EUR $136 \mathrm{~m}$, i.e. $0.28 \%$ of GDP. This means that Croatia, just like all other New Member States, should also be a net recipient of funds from the EU budget. Total net financial position of Croatia due to the EU membership includes also additional costs and benefits of accession like various harmonisations and need for project co-financing at the state and local levels. Even in this variant, Croatia should be in plus to a total amount of EUR $72 \mathrm{~m}$, i.e. $0.15 \%$ of GDP.

The period from 2014-2020 is covered by the new financial perspective of the EU described in the multiannual financial framework. In the proposal of this future financial perspective, that was actual in the time of writing this paper, numerous changes in the EU budget financing system are envisaged; the most important are the abolition of current VAT-based own resources and the introduction of new revenue based on VAT, the introduction of a financial transactions tax, an expected decline in the share of GNI-based own resources of the EU budget and simplification of various correction mechanisms. However, it has to be stressed that for the moment this represents only a proposal and it is highly likely that some of proposed changes will not be adopted in the end. Nevertheless, there is definitely a need to undertake further analyses in order to assess the future implications of these taxes for all participants in the process, i.e. final consumers, the financial sector and government authorities in Croatia.

Apart from changes in the financing of the EU budget, also planned are some changes in financing from the EU budget. Newly proposed changes of financing from the EU funds should bring about a more equal and fair distribution of funds among Member States aimed at maintenance of the Cohesion Policy and Common Agricultural Policy in line with the long term objectives of the EU development. According to the assessment presented in the paper, in the new financial perspective from 2014-2020, Croatia could withdraw funds from the EU funds in total amount of EUR $5.2 \mathrm{bn}$, but it is very important to emphasize that this amount on an annual level increases from EUR 0.4 bn in 2014 to EUR 1.1 bn in 2020. The total amount of funds that Croatia may receive in the period 2014-2020 includes some residual pre-accession assistances, special arrangements and budgetary compensations. This amount is estimated at EUR 6.34 bn, whereby on an annual level it gradually increases from EUR 0.7 bn in 2014 up to EUR 1.2 bn in 2020. By the exponential regression analysis from historical data of all EU Member States it is estimated that the expected Croatian GDP per capita in 2020 would 
imply the net receipt of funds from the EU budget in the total amount of EUR 1.13 bn, i.e. $1.72 \%$ of GDP.

It is important to stress that all figures assessed and elaborated in the paper represent only expectations, taking into account huge number of assumptions and that the final realization of Croatian financial flows from the moment of its accession to the EU in the mid 2013 up to 2020 is attended by numerous uncertainties. It is definitely needed to develop quality strategies for improvements in absorption capacities for the future period governed by the experiences and best practices of New Member States. Comprehensive monitoring of utilizations of withdrawn funds compared to allocated funds should be initiated, as well as projections of possible scenarios for a future period. These types of analyses should indicate all potential imperfections in existing processes and provide clear guidelines for future developments and improvements. Furthermore, broader potential costs and benefits (not necessarily of financial matters) of EU membership have not been elaborated in this paper, for instance, opening the European market to Croatia, development of competitiveness, political, social, regulatory and other changes. 


\section{REFERENCES}

1. Antczak, M., 2003. Do Acceding Countries Need Higher Fiscal Deficits? <ebook>. Available at: <http://www.case.com.pl/upload/publikacja_plik/ 1586612_260.pdf>.

2. Antczak, M., Dabrowski, M. and Gorzelak, M., 2004. Fiscal Challenges Facing the New Member States [online]. Paper for the DG ECFIN Workshop on "Fiscal Surveillance in EMU: New Issues and Challenges", Brussels, November 12,2004. Available at: < http://ec.europa.eu/economy_finance/events/2004/ bxl1104/papers/dabrowski_en.pdf $>$.

3. Antczak, M., Markiewicz, M. and Siwinska, J., 2006. Fiscal pressures on the road to EMU [online]. Background paper to EFN report on "convergence and integration of the new Member States to the Euro Area". Available at: <http:// www.euroframe.org/fileadmin/user_upload/euroframe/efn/spring2006/EFN Spring06_App_Antczak_et_al.pdf $>$.

4. Council directive 112/2006/EC of 28 November 2006 on the common system of value added tax.

5. Council directive 2008/118/EC of 16 December 2008 concerning the general arrangements for excise duty and repealing Directive 92/12/EEC.

6. Council directive 92/12/EEC of 25 February 1992 on the general arrangements for products subject to excise duty and on the holding, movement and monitoring of such products.

7. Council of the European Union, 2005. Financial Perspective 2007-2013.

8. CPMR, 2011. Financial Framework 2014-2020: What is at Stake for Europe's Regions? Technical Paper from the CPMR General Secretariat [online]. Available at: <http://www.crpm.org/pub/docs/329_tp_mff_en.pdf>.

9. Croatian Bureau of Statistics (CBS), 2012. Foreign trade in goods of the Republic of Croatia: January - December 2011. First Release, No. 4.2.1/12. Available at: <http://www.dzs.hr/Hrv Eng/publication/2011/04-02-01 122011 corr.htm>.

10. Cuculić, J., Faulend, M. and Šošić, V., 2004. "Fiscal Aspects of Accession: Can we Enter the European Union with a Budgetary Deficit?". Financial Theory and Practice, 28(2), pp. 155-179. Available at: <http://www.ijf.hr/eng/ EU2/cuculic-faulend-sosic.pdf>.

11. Delegation of the European Union to the Republic of Croatia, 2012. Overview of EU - Croatia relations [online]. Available at: <http://delhrv.ec.europa.eu/ ?lang $=$ en\& content $=62>$.

12. European Commission, 2007a. Screening report Croatia; Chapter 33 - Financial and budgetary provisions.

13. European Commission, 2007b. Pre-allocated funding for heading $1 B$ "Cohesion for growth and jobs" of the Financial Framework. 
14. European Commission, 2007c. Pre-allocated funding for "Rural development" under heading 2 "Natural resources" of the Financial Framework.

15. European Commission, 2009. Five years of an enlarged EU: Economic achievements and challenges.

16. European Commission, 2011a. EU budget 2010 Financial Report.

17. European Commission, 2011b. EU budget 2010 Financial Report-Detailed data 2000-2010.

18. European Commission, 2011c. Croatia 2011 Progress Report.

19. European Commission, 2011d. A Budget for Europe.

20. European Commission, 2011e. A Budget for Europe-Part II: Policy fiches.

21. European Commission, 2011f. A Budget for Europe 2020: the current system of funding, the challenges ahead, the results of stakeholders consultation and different options on the main horizontal and sectoral issues.

22. European Commission, 2011g. Financing the EU Budget: Report on the Operation of the Own Resources System.

23. European Commission, 2011h. European Commission proposal for the 20142020 Multiannual Financial Framework.

24. European Commission, 2011i. Amended proposal for a COUNCIL DECISION on the system of own resources of the European Union.

25. European Commission, 2011j. Amended proposal for a COUNCIL REGULATION laying down implementing measures for the system of own resources of the European Union.

26. European Commission, 2011k. Proposal for a COUNCIL DECISION on the system of own resources of the European Union.

27. European Commission, 2011l. Financing the EU Budget: Report on the Operation of the Own Resources System - Annex.

28. European Commission, 2012. Statement of estimates of the European Commission for the financial year 2013 (Preparation of the 2013 Draft Budget).

29. Eurostat database [online]. Available at: $<$ http://epp.eurostat.ec.europa.eu/portal/page/portal/statistics/search_database $>$.

30. Government of Republic of Croatia, 2010a. Izvješće o ispunjavanju obveza iz poglavlja 16. Porezi [online]. Available at: <http://www.mvep.hr/custompages/static/hrv/files/pregovori/5/p16.pdf>.

31. Government of Republic of Croatia, 2010b. Međuvladina konferencija o pristupanju Republike Hrvatske Europskoj uniji: Dodatak na Pregovaračko stajalište Republike Hrvatske za poglavlje 16. "Porezi” (CONF-HR 8/08) [online]. Available at: <http://www.mvep.hr/custompages/static/hrv/files/ pregovori/4/16a.pdf>. 
32. Hallet, M., 2004. Fiscal Effects of Accession in the New Member States. European Commission. Economic Papers, No 203. [online]. Available at: <http:// ec.europa.eu/economy_finance/publications/publication720_en.pdf>.

33. Halmai, P. and Vásáry, V., 2010. Real Convergence in the New EU Member States of the European Union (Shorter and Longer Term Prospects) [online]. The European Journal of Comparative Economics, 7(1), pp. 229-253. Available at: <http://eaces.liuc.it/18242979201001/182429792010070110.pdf>.

34. House of Lords, 2012. Towards a Financial Transaction Tax? [online]. European Union Committee, 29th Report of Session 2010-12. Available at: <http:/ www.publications.parliament.uk/pa/ld201012/ldselect/ldeucom/287/287. pdf $>$.

35. International Monetary Fund (IMF), 2006. Republic of Lithuania: 2006 Article IV Consultation - Staff Report and Public Information Notice on the Executive Board Discussion [online]. IMF Country Report, No. 06/162. Washington, International Monetary Fund. Available at: <http://www.imf.org/external/ pubs/ft/scr/2006/cr06162.pdf $>$.

36. International Monetary Fund (IMF), 2012a. World Economic Outlook, April 2012 - Growth Resuming. Dangers Remain [online]. Washington: International Monetary Fund. Available at: <http://www.imf.org/external/pubs/ft/ weo/2012/01/pdf/text.pdf $>$.

37. International Monetary Fund (IMF), 2012b. World Economic Outlook Update, July 2012 [online]. Washington: International Monetary Fund. Available at: $<$ http://www.imf.org/external/pubs/ft/weo/2012/update/02/pdf/0712.pdf>.

38. Kandžija, V. and Cvečić, I., 2011. Ekonomika i politika Europske unije. Rijeka: Ekonomski fakultet.

39. Kulhánek, L., 2012. Real convergence in Central and Eastern European EU member states. MPRA Paper, No. 39822 [online]. Available at: <http://mpra. ub.uni-muenchen.de/39822/1/MPRA_paper_39822.pdf $>$.

40. Kuliš, D., 2010. What Is Expected from New Excise Duty Regulations in Croatia? [online]. Press Release, No. 23. Available at: <http://www.ijf.hr/eng/releases/23.pdf $>$.

41. Ministry of Finance Time Series Data [online]. Available at: $<$ http://www. mfin.hr/en/time-series-data>.

42. Ministry of Finance, 2010. Izvješće o korištenju pretpristupnih programa pomoći Europske Unije za razdoblje od 1. srpnja do 31. prosinca 2010. [online]. Available at: <http://www.mfin.hr/adminmax/docs/Sabor\%20II\%20polovica\%202010.pdf>.

43. Ministry of Finance, 2012. Perspektiva sudjelovanja RH u europskim fondovi$m a$ [ppt presentation]. Available at: <http://www.mfin.hr/adminmax/docs/mogucnosti $\% 20 \mathrm{u} \% 20 \mathrm{koristenju} \% 20$ fondova.pps $>$. 
44. Ministry of Foreign and European Affairs, 2011. Conference on Accession to the European Union - Croatia (CONF-HR 17) [online]. Available at: <http:// www.mvep.hr/custompages/static/hrv/files/pregovori/ZSEUEN/33.pdf>.

45. Money-Go-Round.eu database [online]. Available at: $<$ http://www.money-goround.eu/>.

46. Osterloh, S., 2010. The Fiscal Consequences of EU Cohesion Policy after 2013 [online]. Available at: <http://www.ief.es/documentos/recursos/publicaciones/revistas/presu_gasto_publico/57_04.pdf $>$.

47. Sopek, P., 2011. Assessment of impact of accession to the EU on Croatian budget. Newsletter, No. 59 [online]. Available at: $<$ http://www.ijf.hr/eng/newsletter/59.pdf>.

48. Sopek, P., 2012. Tax expenditures and the efficiency of Croatian value added tax. Financial Theory and Practice, 36(3), pp. 269-296 [online]. Available at: <http://www.ijf.hr/upload/files/file/FTP/2012/3/sopek.pdf>. doi: 10.3326/ fintp.36.3.3

49. The European Bank Coordination ("Vienna") Initiative, 2011. The Role of Commercial Banks in the Absorption of EU Funds Report by the Working Group [online]. Available at: <http://ec.europa.eu/economy_finance/articles/ financial_operations/pdf/report_eu_funds_en.pdf $>$.

50. The Excise Duty Act, NN 83/09. Zagreb: Narodne novine.

51. The Institute of Economics, Zagreb, 2012. Priopćenje za javnost u povodu objavljivanja novog broja publikacije Croatian Economic Outlook Quarterly (No. 51, July 2012) [online]. Available at: <http://www.eizg.hr/Download. ashx?FileID=528a7b1b-e26f-42b0-9c1a-4097209a1b11>.

52. The Regulation on Excise Duty Rate on Cigarettes, NN 102/10. Zagreb: Narodne novine.

53. Vojinović, B. and Oplotnik, Ž. J., 2008. Real Convergence in the New EU Member States [online]. Prague Economic Papers, 1. Available at: $<$ http:// www.vse.cz/polek/download.php?.jnl=pep\&pdf=317.pdf $>$. 